\title{
Analiza błędów w przekładzie unijnych aktów normatywnych na przykładzie Council Regulation (EC) no 1346/2000 of 29 May 2000 on Insolvency Proceedings.
}

\section{The Analysis of Mistakes and Errors Occuring in the Translation of the Council Regulation (EC) no 1346/2000 of 29 May 2000 on Insolvency Proceedings.}

\author{
Paulina Nowak \\ Instytut Językoznawstwa, Uniwersytet im. Adama Mickiewicza \\ ul. Międzychodzka 5, 60 - 371 Poznań, POLAND \\ paulina.nowak@gmail.com
}

\begin{abstract}
This paper deals with the analysis of mistakes and errors in the translation of the Council Regulation (EC) no 1346/2000 of 29 May 2000 on insolvency proceedings from English into Polish. This article presents a selection of examples from English and French versions together with their incorrect translations into Polish by UKIE with the author's suggestions of correct equivalents. There is also a short description of the spotted types of language and translation method applied (or no translation method applied), syntactic and grammatical differences in Polish and English, as well as culturally-conditioned differences in Polish and English legal realities.
\end{abstract}

\section{Wstęp}

Celem niniejszego artykułu jest analiza błędów występujących w thumaczeniu tekstu unijnego rozporządzenia, a dokładniej Rozporządzenia $\mathrm{nr}$ 1346/2000 z dnia 29 maja 2000 r. (Council Regulation (EC) no 1346/2000 of 29 May 2000 on Insolvency Proceedings) w sprawie postępowania upadłościowego, regulującego skutki międzynarodowego postępowania upadłościowego lub naprawczego prowadzonego w jednym z Państw Członkowskich Unii Europejskiej, z języka angielskiego na polski. Powyższe rozporządzenie jest podstawowym aktem prawnym dotyczącym postępowania upadłościowego $\mathrm{w}$ prawie Unii Europejskiej i wiąże wszystkie państwa Unii $\mathrm{z}$ wyjątkiem Danii. Analizie porównawczej poddane zostały teksty wyżej wspomnianego rozporządzenia unijnego w trzech wersjach językowych:

$>$ polskiej - Rozporządzenie Rady (WE) nr 1346/2000 z dnia 29 maja 2000 r. w sprawie postępowania upadłościowego (wersje thumaczenia UKIE z 2003 i 2004r.);

$>$ angielskiej - Council Regulation (EC) no 1346/2000 of 29 May 2000 on insolvency proceedings;

$>$ francuskiej - Règlement (CE) $N^{\circ} 1346 / 200$ du Conseil du 29 mai 2000 relatif aux procédures d'insolvabilité; 
Powyższe wersje $\mathrm{w}$ języku angielskim i francuskim zostały pobrane za pomocą aplikacji internetowej EUR-Lex ${ }^{1}$, która umożliwia bezpośredni dostęp do prawa Unii Europejskiej (a ściślej do Dziennika Urzędowego Unii Europejskiej). Polskie wersje rozporządzenia, zaproponowane przez Urząd Komitetu Integracji Europejskiej w 2003 i 2004 roku, pobrane zostały z EUR-Lex ${ }^{2}$, przy wykorzystaniu linku znajdującego się na stronie internetowej $\mathrm{UKIE}^{3}$. Obie wersje, zaproponowane przez Urząd Komitetu Integracji Europejskiej w 2003 i 2004 roku, zawierały liczne błędy i w związku z tym, natychmiast po skandalu jakie wywołały, zostały usunięte z bazy dokumentów unijnych. Błędy te są dowodem nie tylko niedbałości i braku odpowiednich kwalifikacji, ale świadczą także o miernym przygotowaniu merytorycznym autorów. Ponadto, różnice $\mathrm{w}$ rzeczywistości prawnej polskiej i angielskiej są znacznie większe, niż w przypadku polskiej i francuskiej, co niejednokrotnie było przyczyną powstawania błędów w procesie tłumaczenia rozporządzenia nr 1346/2000 na język polski. Wielu błędów można było uniknąć thumacząc bezpośrednio z tekstu francuskiego na język polski. Należy przy tym podkreślić, że błędy w thumaczeniu tekstów prawnych mogą prowadzić do zmiany treści przepisów, uniemożliwiając tym samym ich właściwe stosowanie. Opieranie się na takim tekście $\mathrm{z}$ błędami pociąga za sobą poważne konsekwencje zarówno dla polskich przedsiębiorstw, państwa jak i gospodarki, ale najbardziej ucierpi zwykły, polski obywatel, który poniesie największe konsekwencje wynikające z błędów w przekładzie.

\section{Typologia błędów}

Błędy w thumaczeniu mogą mieć różnorodny charakter i mogą być wynikiem działania różnorakich czynników. Mogą pojawić się z braku odpowiedniej wiedzy na temat zasad przekładu, czy też z braku odpowiedniej metody przekładowej. Błędy $w$ thumaczeniach są niekiedy wynikiem niewiedzy tłumacza na poziomie językowym lub na poziomie znajomości dziedziny, do której należy tekst wyjściowy. Dzierżanowska (1990), przedstawiając uniwersalną klasyfikację błędów w thumaczeniu, stworzoną z punktu widzenia przekładu z języka polskiego na angielski, wyróżniła następujące typy błędów: (i) błędy ortograficzne (pisownia i interpunkcja); (ii) błędy dotyczące form i konstrukcji gramatycznych (formy morfologiczne; elementy struktury grupy wyrazowej; elementy struktury zdania - a więc błędy morfologiczne, składniowe, frazeologiczne); (iii) błędy dotyczące szyku wyrazów i części zdania; (iv) błędy leksykalne (wyraz, grupa wyrazowa); (v) błędy polegające na braku adekwatności sytuacyjnej, semantycznej oraz stylistycznej. W obrębie każdej grupy, Dzierżanowska (1990) wyróżnia błędy spowodowane interferencją zewnętrzną oraz błędy spowodowane interferencją wewnętrzną.

Grucza (1978: 17) definiuje zjawisko interferencji w następujący sposób: „Tam, gdzie między uprzednio zinternalizowanym materiałem językowym a materiałem przyswajanym aktualnie zachodzi identyczność strukturalna, będziemy mieli do czynienia z tzw. transferem pozytywnym, natomiast tam, gdzie zachodzi odmienność strukturalna, może wystąpić zjawisko tzw. transferu negatywnego, który w lingwistyce i glottodydaktyce nazywa się zwykle interferencją. Interferencja jest więc zjawiskiem niepożądanym, prowadzi bowiem do tworzenia błędnych struktur i błędnych realizacji”. Interferencja może być: (i) interlingwalna (zewnętrzna), kiedy pod wpływem jednego języka powstają błędy w drugim języku, oraz (ii) intralingwalna (wewnętrzna), gdy błąd powstaje w ramach jednego języka (Dzierżanowska 1990: 29). Ponadto, „warunkiem dobrego thumaczenia jest to, by thumacz był świadomy niebezpieczeństw, na jakie jest narażony w trakcie wykonywania swej pracy. Są one związane $w$ przeważającej mierze $\mathrm{z}$ działaniem interferencji zarówno zewnętrznej jak i wewnętrznej” (Dzierżanowska 1990: 77).

Grucza (1978: 13), sygnalizuje potrzebę odróżnienia dwóch zasadniczo różnych kategorii błędów, a mianowicie: błędów sensu stricto (popełnionych na skutek nieopanowania lub niedostatecznego opanowania danego języka, więc wynikających z niepełnej kompetencji - braku wiedzy) jak również z pomyłek językowych lub błędów sensu largo (popełnionych albo popełnianych przez kompetentnych użytkowników danego języka, a więc takich, którzy są w stanie owe błędy

\footnotetext{
${ }^{1} \mathrm{http} / / /$ europa.eu.int/eur-lex

${ }^{2} \mathrm{http} / / / \mathrm{www}$.europa.eu.int/eur-lex/de/accession.html

${ }^{3}$ http://www2.ukie.gov.pl
} 
skorygować). Warto przy tym dodać, że niektóre języki mają odrębne wyrazy na ich oznaczenie, np.: ang. errors i mistakes, fr. erreurs et fautes. Wedhug Pisarskiej i Tomaszkiewicz (1996: 144), najogólniej błędy można podzielić na dwie główne kategorie: błędy językowe i błędy tłumaczeniowe. Podobnej klasyfikacji dokonuje Kozłowska, (2002: 138): ,jeśli chodzi o błędy spotykane w przekładach (tekstach polskich przekładów), to od strony dydaktyki translacyjnej można - niezależnie od języka, z którego się tłumaczy (poza błędami logicznymi, redakcyjno-technicznymi i drukarskimi) wyróżnić dwa typy błędów: 1 . Błędy widoczne bez porównywania $\mathrm{z}$ tekstem oryginału, czyli zauważalne dla czytelnika polskiego, tzn. dla rodzimego użytkownika języka polskiego; 2. Błędy wykrywalne podczas porównywania $z$ tekstem oryginału. Pierwsze nazywać będziemy błędami językowymi, drugie - błędami tłumaczeniowymi (ewentualnie błędami thumaczeniowymi sensu stricto)".

Błędy językowe mogą występować zarówno w tekstach docelowych (przekładu), jak również w tekstach źródłowych (oryginału). Błędy tłumaczeniowe występują zasadniczo w tekstach tłumaczonych, i polegają z reguły na niewłaściwym przekazaniu treści oryginału. Jednak, może zaistnieć taka sytuacja, kiedy to w tekście źródłowym, (który jest już tekstem tłumaczenia) pojawi się pewien fragment źle przetłumaczony i wówczas będzie to błąd thumaczeniowy w tekście źródłowym. „Tak więc w tekście thumaczonym mogą wystąpić zarówno błędy językowe, jak i błędy thumaczeniowe. Charakter tych błędów jest jednak (...) inny. Inne są też przyczyny powstawania tych dwóch rodzajów błędów. Błędy thumaczeniowe wynikają $\mathrm{z}$ niezrozumienia tekstu oryginału, braku kompetencji kulturowej bądź wiedzy specjalistycznej oraz niestaranności, pośpiechu, niedbalstwa, nieuwagi. Główną przyczyną błędów językowych (...) nie jest nieznajomość języka przekładu, który jest przecież językiem ojczystym ale interferencja. Przejawia się ona na wszystkich poziomach (graficznym, morfologicznym, składniowym, leksykalnym i słowotwórczym)" (Kozłowska 2002: 137).

Ciekawego podziału błędów w thumaczeniu na język ojczysty dokonuje Hejwowski (2002: 158), który dzieli je w następujący sposób: 1) błędy interpretacji (wynikające z niezrozumienia intencji autora, braku wiedzy potrzebnej do zinterpretowania danego tekstu, lub $\mathrm{z}$ niewystarczającej znajomość oryginału); 2) błędy thumaczenia powierzchniowego (kalki językowe różnego typu, np.: leksykalno-frazeologiczne, syntaktyczne, kalkowanie struktury tematyczno-rematycznej zdania); 3) błędy realizacji (błędy językowe spowodowane niewystarczającą znajomością języka ojczystego, jak również błędne decyzje wynikające ze złej oceny wiedzy odbiorcy, co w konsekwencji może doprowadzić do dostarczenia odbiorcy tekstu, który jest dla niego niezrozumiały, albo przeciwnie zawiera informacje zbyt oczywiste, zbędne; 4) błędy metatranslacyjne (polegające na niezrozumieniu sensu działalności tłumaczeniowej, nieznajomości zasad i reguł tłumaczeniowych).

Próby klasyfikacji błędów w thumaczeniu dokonuje również Karczewska (2004: 130), która bada głównie błędy thumaczeniowe sensu stricto. Błędem thumaczeniowym sensu stricto nazywa „wszelkie zmiany $\mathrm{w}$ warstwie semantycznej, pragmatycznej i (lub) stylistycznej w tekście tłumaczenia w stosunku do oryginału, które wypaczają jego sens oraz intencje nadawcy komunikatu wyjściowego". Błędy tłumaczeniowe sensu stricto dzieli na: błędy w planie wyrażania oraz błędy w planie treści. „W pierwszym wypadku idzie nie tylko o przekazanie treści (ta, jak wiadomo, jest zawsze najistotniejsza), ale o nadawanie tej treści właściwej formy. Podstawą wyodrębnienia grupy pierwszej jest więc element $\mathrm{w}$ warstwie powierzchniowej tekstu, innymi słowy, wykładnik treści. Błędy w tej kategorii polegają na niewłaściwym wyborze ekwiwalentu lub ekwiwalentów. W drugim wypadku, elementem decydującym o przynależności bądź nie danego fragmentu przekładu do kategorii błędów w planie treści jest poprawność przekazania treści komunikatu wyjściowego. Wybór właściwej strategii translacyjnej jest poniekąd sprawą drugorzędną" (Karczewska 2004: 130).

W praktyce, sklasyfikowanie błędów, napotkanych w rozporządzeniu nr 1346/2000, według wyżej wymienionych kryteriów, okazało się jednak niemożliwe. Powyższe podziały, nie pozwoliły na jednoznaczne uporządkowanie błędów, prowadząc do powstawania licznych niespójności. Wszystkie błędy występujące w tłumaczeniach można przecież uznać za językowe i thumaczeniowe jednocześnie, bo błąd językowy powstający w procesie przekładu jest zarazem błędem thumaczeniowym. Ponadto, bardzo często zdarza się, że błędy występujące w rozporządzeniu po prostu nakładają się na siebie, np.: błąd gramatyczny może być jednocześnie błędem terminologicznym itp. 
Dlatego też, dla celów niniejszego artykułu, błędy z rozporządzenia nr 1346/2000 zostaną sklasyfikowane i omówione w następujący sposób:

$>$ błędy ortograficzne;

$>$ błędy interpunkcyjne;

$>$ błędy stylistyczne;

$>$ błędy gramatyczne (fleksyjne i składniowe);

$>$ błędy leksykalne (frazeologiczne, neologizmy leksykalne, zmiana znaczenia);

$>$ pozostałe błędy (dodanie, opuszczenie, nonsens, inne przypadki zmiany znaczenia).

\subsection{Błędy ortograficzne}

Błędy ortograficzne świadczą o lukach w wykształceniu thumacza, jak również o nieprofesjonalnym podejściu do powierzonego mu zadania. Tłumacze pisemni mają, bowiem możliwość uniknięcia błędów językowych, ponieważ tłumacząc, mają dostęp do wszelkiego rodzaju słowników, z których korzystanie jest wręcz wymagane. Błędy ortograficzne dotyczą głównie pisowni. Szczegółowej charakterystyki błędów ortograficznych, powstających $\mathrm{w}$ trakcie przekładu z języka angielskiego na polski dokonuje Dzierżanowska (1990: 78):

a) błędy ortograficzne powstałe $\mathrm{w}$ thumaczeniu mogą wynikać $\mathrm{z}$ podobieństw miedzy słowami polskimi i angielskimi, które mają podobne brzmienie i genezę, ale których formy wykazują jednak pewne różnice. Na przykład: Antarktyda = Antarctica; dezorganizacja = disorganization. W przypadku tłumaczenia na język polski, słowo Antarctica często thumaczone jest jako Antarktyka zamiast Antarktyda. Podobnie w przypadku słowa dezorganizacja, które może być przetłumaczone błędnie na język angielski jako desorganization zamiast disorganization.

b) ponadto, błędotwórczy wpływ języka polskiego na język angielski zaobserwować można również w zakresie przenoszenia wyrazów. W języku polskim podstawą dzielenia wyrazów jest sylaba, podczas gdy w języku angielskim dzielenie wyrazów odbywa się według kryteriów morfologicznych i etymologicznych.

c) jeszcze inne błędy mogą wynikać $\mathrm{z}$ drobnych aczkolwiek istniejących różnic $\mathrm{w}$ ręcznym pisaniu symboli graficznych. Na przykład: angielskie duże ,jot” (J) przypomina raczej polskie duże „te” pisane po angielsku T.

d) ,interferencja wewnętrzna jest często rezultatem zjawiska homofonii, tj. występowania form identycznych pod względem fonetycznym w tym samym języku, lecz różniących się pisownią, pochodzeniem i znaczeniem" (Dzierżanowska 1990: 79).

Na przykład: complement/compliment; air/heir.

e) istnieją również wyrazy, które różnią się wymową, aczkolwiek różnice te są tak minimalne, że nie zawsze dają się usłyszeć (to) accept/except.

f) wyrazy pochodzące od tego samego rdzenia, które wykazują jednak różnice w pisowni, także mogą być przyczyną błędów: four, fourteen ale forty. Częstym błędem jest używanie formy fourty, zamiast forty.

g) błędy ortograficzne powstają również w pisowni wyrazów pisanych łącznie lub rozdzielnie, np.: short sight pisane jest rozdzielnie; natomiast short-sighted pisane jest z łącznikiem. Ponadto, istnieją znaczne rozbieżności między odmianą języka angielskiego brytyjskiego a amerykańskiego. Brytyjczycy piszą swimming-pool, natomiast Amerykanie: swimming pool.

Błędy ortograficzne, które pojawiły się w rozporządzeniu nr 1346/2000 można podzielić na dwie grupy:

$>$ błędy dotyczące niewłásiwego używania wielkich i małych liter;

$>$ błędy wynikające z niewłaściwej litery w zapisie. 


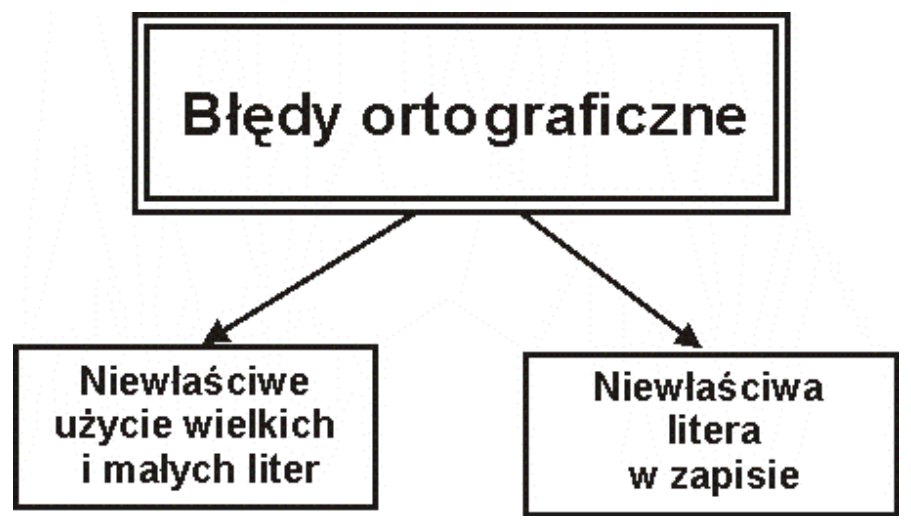

Schemat 1: Podziat btędów ortograficznych

Oto przykłady błędów ortograficznych występujących w rozporządzeniu nr 1346/2000:

Niewłaściwe używanie wielkich i małych liter

Przykład 1:

$>\mathrm{w}$ art. 4 podczas przekładu angielskiego terminu: hereafter reffered to as the State of the opening of proceedings (franc. ci - après dénommé État d'ouverture) powstał błąd ortograficzny na poziomie pisowni, dotyczący użycia małej litery zamiast wielkiej; tak więc zamiast: określonego dalej jako Państwo wszczęcia postępowania tłumacz napisał: zwanego dalej państwem wszczęcia postępowania z małej litery zamiast wielkiej. Państwo wszczęcia postępowania jest terminem zdefiniowanym $\mathrm{w}$ rozporządzeniu, dlatego też traktowany jest jako nazwa własna i pisany jest $\mathrm{z}$ wielkiej litery. Termin ten oznacza państwo unijne. Natomiast państwo wszczęcia postępowania, pisane z małej litery oznacza państwo unijne lub jakiekolwiek inne państwo poza Unią.

Niewłaściwa litera w zapisie

Przykład 1:

$>\mathrm{w}$ art. $35 \mathrm{w}$ przekładzie terminu proceedings (franc. procédure) powstał błąd ortograficzny, w którym zamiast: postępowanie tłumacz napisał postepowanie. Błąd ten można byłoby zaklasyfikować jako błąd drukarski, niemniej jednak błędy tego typu pojawiają się tak często, że zostały one uznane za błędy ortograficzne.

\subsection{Błędy interpunkcyjne}

Błędy interpunkcyjne są to błędy, które polegają na niestosownym użyciu lub pominięciu któregokolwiek ze znaków przestankowych (np.: kropki, przecinka, dwukropka, średnika, wykrzyknika, pytajnika, wielokropka, myślnika, nawiasu, oraz cudzysłowu). Szczegółowej analizy błędów interpunkcyjnych, występujących w thumaczeniach z języka angielskiego na polski dokonuje Dzierżanowska (1990: 81).

Do najpospolitszych błędów interpunkcyjnych należy niepotrzebne użycie lub pominięcie przecinka. Błędy interpunkcyjne w przekładzie na język angielski, mogą powstać na skutek interferencji języka polskiego, ponieważ istnieją poważne rozbieżności między systemem polskim a angielskim, dotyczące reguł stawiania przecinków. W języku angielskim, „nie stawia się przecinka przed rzeczownikowym zdaniem podrzędnym zaczynającym się od that $=\dot{z} e$; przecinek można natomiast postawić przed and $=i$, gdy spójnik ten łączy dwa zadania współrzędne czego nie robi się w języku polskim; natomiast $\mathrm{w}$ niektórych przypadkach opuszcza się przecinek między zdaniem głównym a podrzędnym (...), w pisowni liczb przecinek oddziela setki od tysięcy, a kropka (i to nieco powyżej od poziomu dolnej linii) - części dziesiętne od całości, czyli akurat odwrotnie niż w notacji polskiej; w nagłówkach listów angielskich stawia się przecinek (Dear Mother,), a w polskich wykrzyknik (Droga mamo!)” (Dzierżanowska 1990: 81).

Błędy interpunkcyjne są także wynikiem niewłaściwego użycia myślnika (dash), który w języku angielskim oznacza nagłą przerwę, bądź też zmianę w procesie myślenia. W języku polskim natomiast, stosuje się raczej w tym przypadku wielokropek. „Inaczej używa się łącznika (hyphen), który występuje np.: w angielskich liczebnikach dwuczłonowych (twenty-two), czego nie robi się w pisowni polskiej (dwadzieścia dwa)" (Dzierżanowska 1990: 81). 
Cudzysłów w języku angielskim ma szersze zastosowanie i inną formę graficzną niż w języku polskim, przy czym obydwa człony znajdują się w górnej frakcji. W odmianie brytyjskiej języka angielskiego stosuje się ponadto pojedynczy cudzysłów, służący do oznaczenia cytatu głównego, podczas gdy cudzysłów podwójny służy do wyróżniania jednego cytatu w ramach drugiego. W amerykańskiej odmianie języka angielskiego sytuacja przedstawia się natomiast odwrotnie, co może powodować błędy interferencji wewnętrznej. W języku polskim, nie używa się na ogół pojedynczego cudzysłowu.

„Średnika używa się znacznie częściej w tekstach angielskich niż w polskich, np. dla oddzielania podgrup (The chief commodities are butter, cheese, milk, eggs; lamb, beef, veal, pork, oats, barley, rye, and wheat). W języku polskim należałoby użyć pewnych słownych uściśleń; wówczas w thumaczeniu mielibyśmy np: Gtównymi towarami sa masto, ser, mleko i jajka, a także baranina, wolowina, cielęcina $i$ wieprzowina, ponadto - owies, jęczmień, żyto i pszenica" (Dzierżanowska 1990: 82).

Dwukropka używa się częściej w języku polskim niż w angielskim. W miejscu, gdzie w języku polskim występuje dwukropek, w języku angielskim wystąpi przecinek, średnik a nawet myślnik. Błędy interpunkcyjne, występujące w rozporządzeniu nr 1346/2000 polegają głównie na:

$>$ braku znaku interpunkcyjnego;

$>$ zbędnym użyciu znaku interpunkcyjnego;

$>$ użyciu niewłaściwego znaku interpunkcyjnego.

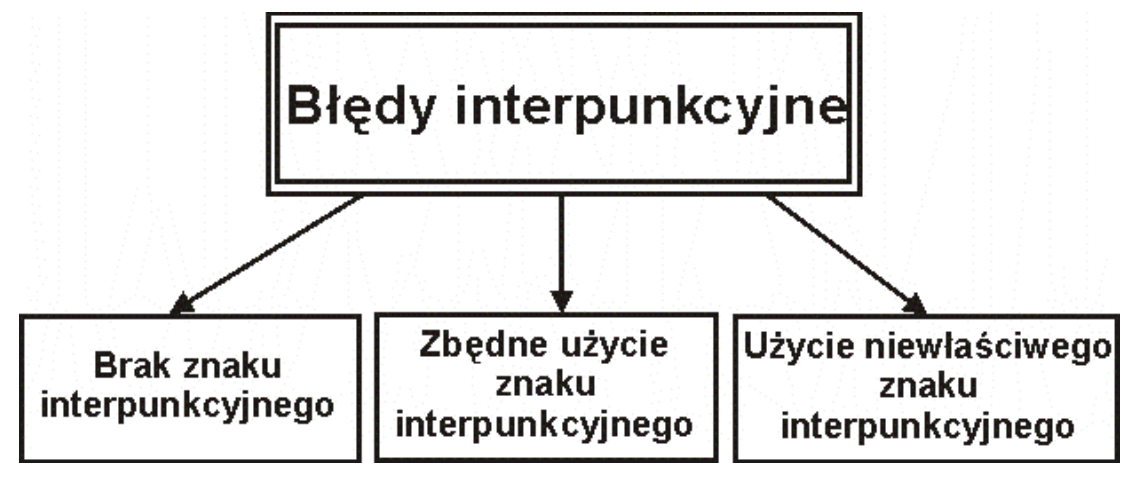

Schemat 2: Podziat błędów interpunkcyjnych

Wyżej wymienione grupy błędów interpunkcyjnych, pojawiające się w rozporządzeniu nr 1346/2000 dotyczą głównie zastosowania kropki oraz przecinka. Oto niektóre przykłady:

Brak znaku interpunkcyjnego

Przykład 1:

$>$ w art. 2 lit. b) brakuje przecinka przed bądź w przykładzie: „syndyk” oznacza każdą osobę lub organ, którego zadaniem jest zarządzanie lub likwidacja aktywów dłużnika [...] bądź nadzór nad prowadzeniem jego interesów. Lista tych osób lub organów znajduje się w załączniku C; podczas gdy zdanie to powinno być przetłumaczone w następujący sposób: „zarządca zagraniczny" oznacza każdą osobę lub organ, którego zadaniem jest zarządzanie majątkiem lub likwidacja majątku dłużnika, bądź nadzorowanie jego działalności gospodarczej. Lista tych osób i organów znajduje się w załączniku C; Mamy w tym przypadku również do czynienia z zakłóceniem związku rządu, jak i błędami terminologicznymi.

Przykład 2:

w art. 3 ust. 4 lit. b) brakuje kropki na końcu zdania: z wnioskiem o wszczęcie terytorialnego postępowania upadłościowego wystąpił wierzyciel, który na stałeprzebywa, ma miejsce zamieszkania lub posiada statutową siedzibę w Państwie Członkowskich, na terytorium którego dłużnik prowadzi działalność lub którego roszczenie wynika z tej działalności_W tym fragmencie występują również błędy terminologiczne, błąd dotyczący braku spacji, czy też złej końcówki fleksyjnej. 
Zbędne użycie znaku interpunkcyjnego

Przykład 1:

$>\mathrm{w}$ art. 4 ust. $2 \mathrm{w}$ tłumaczeniu wystąpił błąd interpunkcyjny polegający na zbędnym użyciu znaku przystankowego, a dokładniej kropki. Tak więc zamiast zamknięcia tych postępowań. występuje zamknięcia tych postępowań.

Przykład 2:

$>\mathrm{w}$ art. $37 \mathrm{w}$ tłumaczeniu na język polski jest postępowanielikwidacyjne,, zamiast postępowanie likwidacyjne, $\mathrm{W}$ powyższym przykładzie mamy zatem do czynienia $\mathrm{z}$ podwójnym, nieuzasadnionym użyciem przecinka i jednocześnie brakiem spacji.

Przykład 3:

> w art. 3 ust. 2 doszło do zbędnego użycia przecinka w przykładzie: w przypadku gdy centrum podstawowych interesów dłużnika znajduje się na terytorium jednego Państwa Członkowskiego, wówczas sądy innego Państwa Członkowskiego są właściwe do wszczynania postępowania upadłościowego wobec tego dłużnika tylko, jeżeli prowadzi on działalność gospodarczą na terytorium tego drugiego Państwa Członkowskiego. W tym przypadku występuje również błąd frazeologiczny, jak i brak spójności terminologicznej.

Użycie niewłaściwego znaku interpunkcyjnego

Przykład 1:

$>\mathrm{w}$ preambule wielokrotnie pojawia się błąd, polegający na zastosowaniu kropki zamiast średnika.

Przykład 2:

$>$ w art. 2 lit. e) występuje łącznik zamiast myślnika.

\subsection{Błędy stylistyczne}

Błędy na poziomie stylistyki tekstu, Dzierżanowska (1990: 100) określa mianem „nieadekwatności stylistycznej”. „Nieadekwatność stylistyczna przejawia się wtedy, gdy w przetłumaczonym tekście występują cechy specyficzne dla stylu języka oryginału, a obce dla języka przekładu. (...) Jednolitość stylu jest bardzo ważną zasadą $\mathrm{w}$ thumaczeniu. Tekst pisany mieszaniną stylów czyta się źle" (Dzierżanowska 1990: 100). Do ogólnych przesłanek poprawności stylu należą: jednorodność, dostosowanie do sytuacji komunikacyjnej, poprawność ortograficzna i gramatyczna, jednoznaczność oraz zwięzłość. W wielu przypadkach, osoby tłumaczące na język angielski nadużywają wyrażeń kolokwialnych lub gwarowych w tekstach pisanych stylem urzędowym lub mieszają formy brytyjskie z amerykańskimi. Do najczęstszych błędów stylistycznych należą: używanie elementów oficjalnych $\mathrm{w}$ wypowiedziach potocznych, używanie elementów potocznych o charakterze publicznym, stylizacja językowa niemająca uzasadnienia $\mathrm{w}$ treści i charakterze stylowym wypowiedzi, mało spójne konstrukcje składniowe, brak spójności pod względem treści. Ponadto, do błędów stylistycznych zaliczyć można niezamierzoną tautologię oraz nieudane porównania czy metafory.

„Nadużywanie metafor, słów abstrakcyjnych oraz wyrazów pochodzenia greckiego lub łacińskiego należy do manieryzmów zwalczanych przez stylistów angielskich, a dość często występujących w języku polskim" (Dzierżanowska 1990: 100).

Wśród błędów stylistycznych występujących w rozporządzeniu nr 1346/2000 wystąpiły błędy, gdzie zamiast stylu języka prawnego pojawił się styl języka prawniczego albo potocznego. Podział języka prawa na język prawny i prawniczy zaproponował Wróblewski (1948), określając język prawny jako język aktów prawodawczych, natomiast język prawniczy jako język, którym posługują się prawnicy mający do czynienia z prawem, tj. język komentarzy prawniczych, wystąpień obrońców, dokumentów sądowych, rozpraw naukowych. Tekst prawny to tekst utworzony w języku prawnym według określonych reguł stylistycznych, stosowanych zgodnie z niepisaną tradycją, ale również zredagowanych przez prawodawcę $\mathrm{w}$ formie zasad techniki prawodawczej. Ustawodawca polski, w zbiorze dyrektyw legislacyjnych, wydanych w formie rozporządzenia Prezesa Rady Ministrów z dnia 20 czerwca 2002 r. w sprawie „Zasad techniki prawodawczej” (ZTP, Dz. U. z 2002 r. Nr 100, 
poz. 108), szczegółowo kształtuje stylistykę, narzuca gotowe formuły i utrwala specyficzne cechy tekstów prawnych. Tekst analizowanego rozporządzenia nr 1346/2000 jest niewątpliwie tekstem sformułowanym w języku prawnym.

Błędy stylistyczne występujące w rozporządzeniu nr 1346/2000 podzielone zostały następująco:

$>$ błędy dotyczące użycia języka prawniczego zamiast prawnego;

$>$ błędy związane z użyciem języka potocznego zamiast specjalistycznego (prawnego);

$>$ błędy wynikające z użycia języka literackiego zamiast specjalistycznego (prawnego).

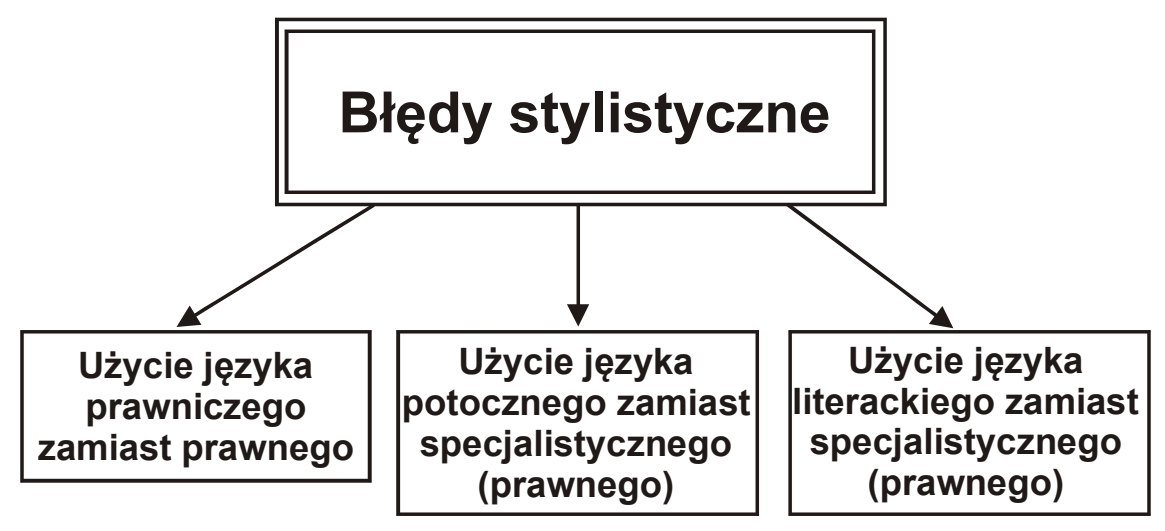

Schemat 3. Podziat błędów stylistycznych

Oto przykłady błędów stylistycznych, występujących w rozporządzeniu nr 1346/2000.

Użycie języka prawniczego, zamiast prawnego

Przykład 1:

$>$ w art. 4 ust. 2 lit. f) fragment with the exception of law suits pending (franc. à l'exception des instances en cours) został błędnie przetłumaczony na język polski jako z wyjątkiem spraw zawisłych przed sądem, zamiast $\mathrm{z}$ wyłączeniem toczących się postępowań. Jest to błąd stylistyczny polegający na zastosowaniu języka prawniczego. Wyrażenie to może być stosowane w języku prawniczym, ale nie w prawnym. Nie jest to jednak błąd prowadzący do zmiany znaczenia.

Przykład 2:

$>$ art. 4 ust. 2 lit. g) zdanie the treatment of claims arising after the opening of insolvency proceedings przetłumaczono jako zaspokajanie roszczeń po otwarciu postępowania upadłościowego zamiast sposób postępowania $\mathrm{z}$ wierzytelnościami powstałymi po wszczęciu postępowania $\mathrm{w}$ sprawie niewypłacalności. Przykład ten ilustruje użycie języka prawniczego zamiast prawnego. Jest to błąd prowadzący do zmiany znaczenia.

Przykład 3:

$\nu_{\mathrm{w}}$ art. 6 ust. 1 wystąpił kolejny błąd stylistyczny w trakcie przekładu angielskiego zdania: where such a set-off is permitted by the law applicable to the insolvent debtor's claim (franc. lorsque cette compensation est permise par la loi applicable à la créance du débiteur insolvable). Zdanie przetłumaczono błędnie na język polski jako o ile na takie potrącenie zezwala prawo regulujące roszczenia dłużnika zamiast: jeśli takie potrącenie jest dopuszczalne zgodnie z prawem właściwym dla wierzytelności niewypłacalnego dłużnika. Nastąiła zmiana znaczenia.

Zastosowanie języka potocznego zamiast prawnego

Przykład 1:

$>\mathrm{w}$ art. 4 angielski termin law applicable (franc. loi applicable) został przetłumaczony dosłownie $\mathrm{z}$ języka francuskiego jako stosowane prawo zamiast prawo właściwe. Mamy tutaj do czynienia $\mathrm{z}$ zastosowaniem języka potocznego zamiast prawnego, czyli z błędem rejestru. Brak zmiany znaczenia. 
Zastosowanie języka literackiego zamiast języka prawa

Przykład 1:

$>$ w art. 2 lit. c) angielski termin other measure terminating the insolvency (franc. autre mesure mettant fin à l'insolvabilité) został przetłumaczony dosłownie z języka francuskiego jako kładący kres niewypłacalności zamiast usuwający niewypłacalność - co jest wyraźnym błędem rejestru. Zastosowano tutaj język literacki zamiast języka prawa. Nie doszło jednak do zmiany znaczenia.

\subsection{Blędy gramatyczne}

Błędy gramatyczne mogą powstać w:

(i) formach morfologicznych;

(ii) elementach struktury grupy wyrazowej;

(iii) elementach struktury zdania (Dzierżanowska 1990: 82).

Błędy gramatyczne, powstałe $\mathrm{w}$ formach morfologicznych, polegają na tworzeniu form gramatycznych, niezgodnych z ustalonymi normami. Mogą one być spowodowane przez interferencje zewnętrzną. Pod wpływem języka polskiego tłumacz może popełniać zatem takie błędy jak:

a) zastosowanie liczby odpowiadającej polskiemu rzeczownikowi wówczas, gdy angielskiego ekwiwalentu używa się w innej liczbie. Tak więc, rzeczownik włosy zostanie przetłumaczony jako hairs mimo, że w tym sensie hair występuje w angielskim w liczbie pojedynczej;

b) zastąpienie rzeczownika angielskiego nieosobowego, który nie podlega w danym przypadku personifikacji, zaimkiem osobowym rodzaju męskiego lub żeńskiego. Tłumacząc zdanie: Świat pragnie otrzymać wszystko, co mu może dać Ameryka jako The world wants all that America can give him, użyje formy osobowej him, mimo że w danym zdaniu mu oznacza świat (world), który to wyraz zastępuje się zaimkiem rzeczownym itp.

Błędy gramatyczne powstałe $\mathrm{w}$ formach morfologicznych mogą być również spowodowane działaniem interferencji wewnętrznej. Interferencja wewnętrzna może spowodować takie błędy jak:

a) użycie błędnej liczby rzeczownika o nietypowej końcówce. Mimo końcowego $s$ wyrazy takie jak news, economics są rzeczownikami występującymi w liczbie pojedynczej, podczas gdy fish, fowl są formą liczby mnogiej. Jeżeli, pod wpływem zewnętrznej formy takich rzeczowników, użyty zostanie czasownik w niewłaściwej liczbie, powstanie oczywiście błąd (np.: news are good zamiast news is good);

b) „dodanie typowej końcówki liczby mnogiej $s$ do rzeczownika, który ma identyczną formę w obu liczbach. Na przykład: counsel, (adwokat, radca prawny) deer, grouse, salmon, sheep, trout itd. mogą być łączone z czasownikami zarówno liczby pojedynczej, jak i mnogiej, w zależności od kontekstu. Innym przykładem takiego błędu jest używanie data (dane) jako formy liczby pojedynczej, mimo że jest to $w$ zasadzie rzeczownik liczby mnogiej, z jednoczesnym utworzeniem neologizmu datas dla oznaczenia pluralis, co się trafia w amerykańskiej literaturze naukowej" (Dzierżanowska 1990: 84);

c) wybór niewłaściwej formy liczby mnogiej, w przypadku istnienia dwóch wersji różniących się między sobą znaczeniem np.: index (palec wskazujący) ma liczbę mnogą indexes, podczas gdy index (wskaźnik) - indices;

d) tworzenie imiesłowu biernego lub czasu past simple niektórych rzadko używanych czasowników nieregularnych $\mathrm{w}$ sposób regularny, $\mathrm{np} .:$ od czasownika to weave - weaved zamiast wove, woven lub też stosowanie nieprawidłowych form pod wpływem innych czasowników nieregularnych: stack zamiast stuck od czasownika to stick na zasadzie analogii $\mathrm{z}$ to swim, swam, swum.

Błędy gramatyczne, mogą również powstać w elementach struktury grupy wyrazowej. W zakresie interferencji zewnętrznej są to następujące błędy:

a) błędy powstałe na skutek nieprawidłowego doboru przyimków. Na przykład: podziękować $w$ imieniu należy przetłumaczyć: to thank on behalf, mimo, że częstym ekwiwalentem polskiego przyimka $w$ jest angielski przyimek in. Tego typu błędy pojawiają się dosyć często $\mathrm{w}$ thumaczeniach, ponieważ stopień ekwiwalencji przyimków w różnych językach jest $\mathrm{z}$ reguły bardzo niski.

b) błędy dotyczące użycia, tak jak po polsku, rzeczownika w dopełniaczu lub przymiotnika przy tłumaczeniu wyrażeń typu: wystawa psów, odciski palców zamiast premodyfikacji 
rzeczownikowej, to znaczy dog show, finger-prints. Natomiast, przykładem interferencji wewnętrznej może być opuszczenie rodzajnika w niektórych nazwach geograficznych, ponieważ przy tych słowach, w większości przypadków nie jest on używany (np.: France, England ale the Zambia, the Argentina; Paris, London ale the Hague).

Błędy gramatyczne, powstałe w elementach struktury zdania, dotyczą niezgodności elementów struktury zdania, ponieważ okazje do popełnienia błędów w zakresie zgodności elementów struktury zdania są liczne. W obrębie interferencji zewnętrznej, do tej grupy błędów można zaliczyć:

a) niewłaściwy dobór czasów spowodowany brakiem zgodności między czasami polskimi a angielskimi. Błędy te pojawiają się wówczas, gdy tłumacz odruchowo zastępuje czas użyty w języku polskim, czasem angielskim, który wydaje mu się najbardziej odpowiedni. Na przykład: użycie czasu Present Simple lub Present Continuous zamiast Present Perfect dla wyrażenia czynności trwającej od jakiegoś momentu w przeszłości do chwili obecnej i wyrażonej po polsku za pomocą czasu teraźniejszego. W thumaczeniu na język polski, błędy mogą być wynikiem zastąpienia czasu Present Perfect Continuous czasem teraźniejszym, podczas gdy może on być tłumaczony na teraźniejszy albo przeszły, w zależności od sytuacji.

b) sugerowanie się polskim następstwem czasów w zdaniach czasowych lub warunkowych i użycie w języku angielskim w zdaniu podrzędnym Future, tak jak w języku polskim zamiast Present Simple.

c) błędy powstałe przy tłumaczeniu mowy zależnej. W języku angielskim występuje (w niektórych przypadkach) zjawisko back-shift czyli cofnięcie w przeszłość, które nie występuje w języku polskim. Owe cofnięcie w przeszłość może stać się przyczyną powstawania błędów przy tłumaczeniu mowy zależnej.

d) błędy w stosowaniu tzw. verb pattern. W języku polskim po czasowniku przestać można użyć bezokolicznika, np. przestać mówić. Zastosowanie tej formy w angielskim byłoby błędem, bo w tym przypadku to stop łączy się $\mathrm{z}$ rzeczownikiem odsłownym, więc ekwiwalentem polskiego przekładu będzie stop talking. W tym przypadku, różnice między strukturami polskimi, a strukturami angielskimi są ogromne i wielką pomocą w eliminowaniu tego typu błędów są słowniki.

e) stosowanie podwójnego przeczenia. Jest to kolejny błąd niezgodności gramatycznej elementów w zdaniu. Podwójne przeczenie używane w języku polskim, zastosowane w tłumaczeniu na język angielski, może być przyczyną błędów. Na przykład: Nikt nie przyszedt powinno być przetłumaczone na angielski jako Nobody came, z użyciem jednego przeczenia, natomiast tłumaczenie Nobody didn't come jest poważnym błędem.

Błędy gramatyczne w elementach struktury zdania, mogą być również spowodowane działaniem interferencji wewnętrznej, która powoduje powstawanie licznych błędów np.: w zakresie zgodności liczby podmiotu i orzeczenia. Oto niektóre z nich:

a) błędy w zdaniach zawierających podwójny podmiot. Często, w zdaniach zawierających podwójny podmiot np. John and Mary are shoping orzeczenie może zostać omyłkowo dopasowane do drugiego członu podmiotu z jednoczesnym użyciem czasownika z liczbie pojedynczej, zwłaszcza, że nie zawsze podmiot złożony z dwóch wyrazów jest podmiotem podwójnym. W zdaniu Whisky and Soda is my favourite drink orzeczenie występuje w liczbie pojedynczej, bo whisky and soda to nazwa napoju złożona z dwóch rzeczowników i spójnika.

b) błędy mogą się zdarzyć w zdaniach, gdzie podmiotem są nouns of multitude, czyli np.: half, number, lot itd. Następującego zdania: A large number of people were present używa się obok The number of people present was large. $\mathrm{W}$ tym przypadku, przedimek wskazuje czy należy użyć czasownika w liczbie pojedynczej czy mnogiej.

c) „błędy w zgodności liczby podmiotu i orzeczenia mogą wystąpić także wtedy, gdy podmiotem zdania jest jakieś inne zdanie. Na przykład, w zdaniu What terms Bulgaria and Hungary may be ultimately given rests with the Peace conference podmiotem jest część podkreślona. Zgodnie z obowiązującą zasadą, że tego rodzaju zdanie podmiotowe należy traktować jako rzeczownik liczby pojedynczej, orzeczenie jest również w liczbie pojedynczej. Gdyby jednak użyto błędnie liczby mnogiej czasownika, tj. formy rest, byłoby to wynikiem działania interferencji wyrazu terms" (Dzierżanowska 1990: 87). 
Błędy gramatyczne występujące w rozporządzeniu nr 1346/2000 zostały podzielone na:

$>$ błędy fleksyjne;

$>$ błędy składniowe.

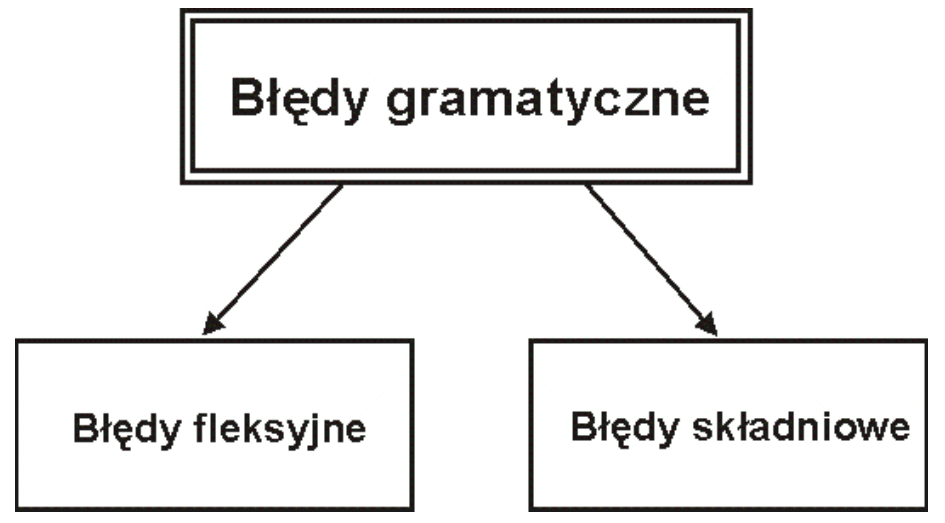

Schemat 4: Podzial błędów gramatycznych

W obrębie błędów fleksyjnych, występujących w rozporządzeniu nr 1346/2000 wyróżnione zostały błędy dotyczące:

wyboru niewłaściwej postaci tematu fleksyjnego;

wyboru niewłaściwej końcówki fleksyjnej.

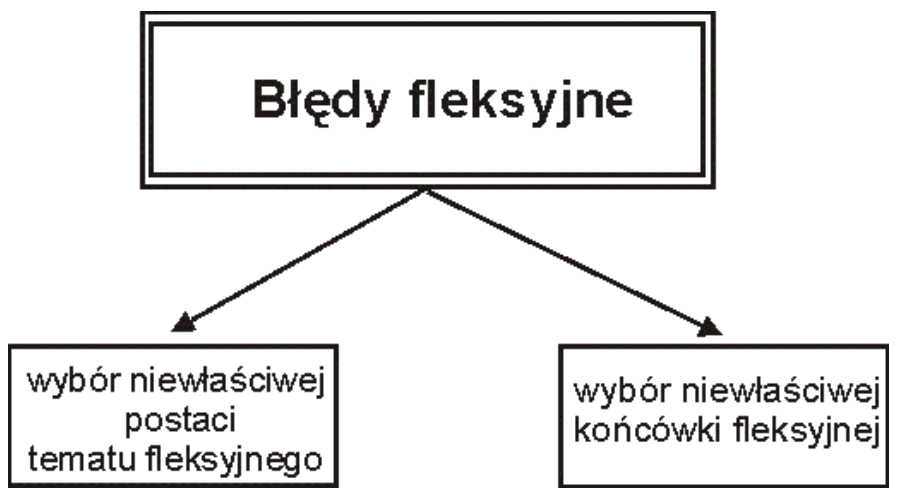

Schemat 5: Podziat błędów fleksyjnych

Oto Przykłady błędów fleksyjnych napotkanych w rozporządzeniu:

Wybór niewłaściwej postaci tematu fleksyjnego

Przykład 1:

$>\mathrm{w}$ art. 17 ust. $1 \mathrm{w}$ polskim przekładzie zamiast jakiekolwiek postępowanie jest jakakolwiek postępowanie. Wystąpił tutaj błąd gramatyczny, wynikający z zastosowania niewłaściwego rodzaju. Tego typu błędy mogłyby również zostać uznane za błędy literowe, lub przypadkowe błędy drukarskie. Niemniej jednak, tego typu błędy pojawiają się bardzo często w rozporządzeniu i wynikają raczej z braku korekty, w związku z czym zostały uznane za błędy gramatyczne.

Wybór niewłaściwej końcówki fleksyjnej

Przykład 1:

$>$ w art. 3 ust. 4 lit. b) podczas przekładu angielskiego terminu in the Member State (franc. dans l'État membre) został popełniony błąd gramatyczny polegający na zastosowaniu niewłaściwej końcówki fleksyjnej. Zamiast w Państwie Członkowskim mamy w Państwie Członkowskich.

Przykład 2:

$>$ w art. 4 ust. 2 lit. a) w thumaczeniu angielskiego fragmentu against which debtors insolvency proceedings may be brought (franc. les débiteurs susceptibles de faire l'objet d'une procédure) 
wystąpił błąd dotyczący wyboru niewłaściwej końcówki fleksyjnej: dłużników, przeciw którym postępowania upadłościowe mogą zostać wszczęta zamiast dłużników, przeciw którym postępowanie w sprawie niewypłacalności może zostać wszczęte. Jednocześnie mamy tu do czynienia z zastosowaniem liczby mnogiej zamiast pojedynczej, przy tłumaczeniu terminu proceedings, który w języku angielskim występuje liczbie pojedynczej jak i mnogiej, ale w tym kontekście proceedings występuje w liczbie mnogiej.

\section{Przykład 3:}

$>$ w art. 16 ust. $2 \mathrm{w}$ thumaczeniu angielskiego fragmentu: recognition of the proceedings referred to in Article 3(1) (franc. la reconnaissance d'une procédure visée à l'article 3, paragraphe 1) wystąpił błąd polegający na wyborze niewłaściwej końcówki fleksyjnej: uznanie postępowania określonej w art. 3 ust. 1 zamiast uznanie postępowania, o którym mowa w art. 3 ust. 1. Jednocześnie mamy tutaj do czynienia z naruszeniem zasad techniki prawodawczej (określony w art.3 zamiast o którym mowa w art. 3).

Do błędów składniowych występujących w rozporządzeniu nr 1346/2000 można zaliczyć:

$>$ zakłócenie związku zgody i rządu;

$>$ błędy w używaniu przyimków;

$>$ konstrukcje niepoprawne pod względem szyku.

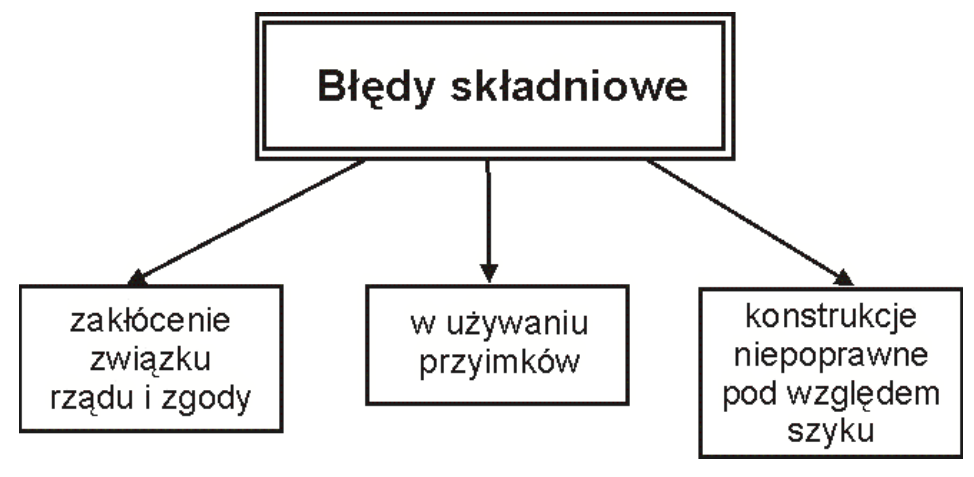

Schemat 6. Podział błędów składniowych

Oto przykłady błędów składniowych zidentyfikowanych w rozporządzeniu:

Zakłócenie związku zgody

Przykład 1:

w preambule, w ust. $20 \mathrm{w}$ thumaczeniu angielskiego zdania: Main insolvency proceedings and secondary proceedings can, however, contribute to the effective realisation of the total assets only if all the concurrent proceedings pending are coordinated (franc. Les procédures principales et les procédures secondaires ne peuvent, toutefois, contribuer à une réalisation efficace de la masse que si toutes les procédures parallèles en cours sont coordonnées) został przetłumaczony błędnie jako: Jednakże postępowania główne i postępowania wtórne mogą przyczyniać się do skutecznej egzekucji wszystkich aktywów tylko [...] przypadku, gdy równoległe toczące się postępowania są koordynowane zamiast Główne i uboczne postępowania w sprawie niewypłacalności przyczyniają się jednakże do skutecznej likwidacji masy tylko wówczas, jeżeli toczące się równolegle postępowania są skoordynowane. W tym przypadku doszło do naruszenia związku zgody. Jednocześnie został pominięty przyimek (tylko [...] przypadku, zamiast tylko w przypadku).

\section{Zakłócenie związku rządu}

\section{Przykład 1:}

$>$ w art. 2 lit. b) w tłumaczeniu na język polski wystąpił błąd gramatyczny, wynikający z zakłócenia związku rządu. Angielski termin to administer or liquidate assets (franc. d'administrer ou de liquider les biens) przetłumaczono jako zarządzanie lub likwidacja aktywów dłużnika zamiast zarządzanie majątkiem lub likwidacja majątku dłużnika. Jednocześnie wystąpił tutaj błąd terminologiczny. 
Przykład 2:

$>$ w preambule, w ust. 25 angielskie zdanie: There is a particular need for a special reference diverging from the law of the opening State in the case of rights in rem, since these are of considerable importance for the granting of credit. The basis, validity and extent of such a right in rem should therefore normally be determined according to the lex situs and not be affected by the opening of insolvency proceedings (franc. Il est particulièrement nécessaire de prévoir pour les droits réels un rattachement particulier qui déroge à la loi de l'État d'ouverture, étant donné que ces droits revêtent une importance considérable pour l'octroi de crédits. La justification, la validité et la portée d'un tel droit réel devraient se déterminer dès lors normalement en vertu de la loi du lieu où il est situé et ne pas être affectés par l'ouverture d'une procédure d'insolvabilité) został błędnie przetłumaczony na język polski jako: Ważne jest szczególne odniesienie do praw rzeczowych, sprzecznych z prawem państwa, w którym wszczynane jest postępowanie, gdyż prawa te przywiązują duże znaczenie do udzielania kredytów. Podstawy, ważność i zakres prawa rzeczowego określane są w zwykły sposób, zgodnie z prawa miejsca położenia (lex situs), nie będąc uzależnione od wszczęcia postępowania upadłościowego, zamiast tłumaczenia: Szczególna potrzeba wprowadzenia regulacji odstępującej od stosowania prawa Państwa wszczęcia postępowania istnieje w przypadku praw rzeczowych, jako że mają one szczególne znaczenie dla udzielania kredytów. Ustanowienie, skuteczność i zakres takiego prawa rzeczowego powinny być zatem określane normalnie zgodnie $\mathrm{z}$ prawem miejsca położenia $\mathrm{i}$ nie powinny zostać naruszone przez wszczęcie postępowania $\mathrm{W}$ sprawie niewypłacalności. W tym przypadku, doszło do zakłócenia związku rządu.

Błąd w używaniu przyimków

Przykład 1:

$>$ w art. 3 ust. 4 lit. a) w trakcie przekładu angielskiego fragmentu because of (franc. en raison de) został popełniony błąd gramatyczny polegający na użyciu podwójnego przyimka: z, ze względu na zamiast ze względu na.

\section{Przykład 2:}

$>$ w art. 2 lit h) angielski fragment with human means and goods (franc. avec des moyens humains et des biens) został przetłumaczony jako z wykorzystaniem zasobów ludzkich i majątkowych, zamiast przy wykorzystaniu zasobów ludzkich i majątkowych co jest błędem w zakresie wyrażenia przyimkowego, jak również zastosowaniem niewłaściwego przypadka.

Przykład 3:

$>\mathrm{w}$ art. $2 \mathrm{w}$ thumaczeniu angielskiego zdania: For the purposes of this Regulation (franc. Aux fins du présent règlement) tłumacz popełnił błąd, używając niewłaściwego przyimka, więc zamiast Dla celów niniejszego rozporządzenia, w tłumaczeniu czytamy Do celów niniejszego rozporządzenia.

\section{Konstrukcje niepoprawne pod względem szyku}

Przykład 1.

$>$ w art. 2. lit. f) angielski fragment the time of the opening of proceedings shall mean time at which the judgment opening proceedings becomes effective, whether it is a final judgment or not (franc. moment de l'ouverture de la procédure: le moment où la décision d'ouverture prend effet, que cette décision soit ou non definitive) został przetłumaczony jako chwila wszczęcia postępowania oznacza chwilę, z którą orzeczenie o wszczęciu postępowania staje się skuteczne, niezależnie od tego czy jest to orzeczenie ostateczne, czy też nie, gdzie zastosowano konstrukcje niepoprawną pod względem szyku. Powyższy fragment powinien zostać przetłumaczony w następujący sposób: chwila wszczęcia postępowania oznacza chwilę, z którą orzeczenie o wszczęciu postępowania staje się skuteczne, niezależnie od tego, czy orzeczenie to jest ostateczne. Brak znajomości składni języka angielskiego u tłumacza.

Przykład 2:

$>\quad$ w art. 26 angielski fragment (...) where the effects of such recognition or enforcement would be manifestly contrary to that State's public policy (franc. lorsque cette reconnaissance ou cette exécution produirait des effets manifestement contraires à son ordre public) przetłumaczono 
z użyciem spójnika i zamiast lub, co doprowadziło do zmiany znaczenia thumaczonego zdania. W wersji polskiej czytamy (...) w przypadku, gdy takie uznanie i wykonanie byłoby wyraźnie sprzeczne $\mathrm{z}$ porządkiem publicznym (...), zamiast (..) o ile skutki takiego uznania lub wykonania stałyby w oczywistej sprzeczności z zasadami współżycia społeczności (...). Jednocześnie mamy tutaj do czynienia z błędem stylistycznym, jak i terminologicznym.

\subsection{Błędy leksykalne}

Błędy leksykalne polegają głównie na użyciu wyrazów w niewłaściwym znaczeniu lub w zniekształconej postaci, albo też na użyciu wyrazu, który nie należy do zasobu polskiego słownictwa. Błędy leksykalne „są (...) spowodowane faktem, że wyrazy w jednym języku rzadko są pełnymi ekwiwalentami wyrazów w innym języku, a zakres ich znaczeń może być zarówno szerszy jak i węższy" (Dzierżanowska 1990: 90). Wiele wyrazów w języku polskim, podobnie jak i w innych językach, to wyrazy wieloznaczne. Wieloznaczność nie stanowi przeszkody w sprawnym porozumiewaniu się, ponieważ wyrazy występują na ogół na tle pewnego kontekstu i sytuacji, co daje wystarczające wskazówki co do tego, które ze znaczeń rozmówca czy też piszący miał na myśli (Kurkowska, Skorupka 2001: 137). Jednakże, w stylu naukowym, w wypowiedziach oficjalnourzędowych, czyli wszędzie tam, gdzie chodzi o terminologię naukową i techniczną, wieloznaczność wyrazów jest niepożądana i często jest przyczyną powstawania błędów. Błędy leksykalne mogą być wynikiem działania interferencji zewnętrznej lub wewnętrznej. Przeważają jednak te, spowodowane interferencją zewnętrzną, wynikające najczęściej z wieloznaczności wyrazów. Dzierżanowska (1990: 90), proponuje następujący podział błędów leksykalnych: (i) błędy dotyczące niezgodności leksykalnej wyrazów; (ii) błędy wynikające z różnic terminologicznych; (iii) błędy wynikające z niezgodności leksykalnej grup wyrazowych.

Błędy dotyczące niezgodności leksykalnej wyrazów, często wynikają ze zjawiska homonimii. Homonimy to „wyrazy jednobrzmiące i często jednakowo pisane, ale o różnym pochodzeniu I wartości znaczeniowej" (Kurkowska, Skorupka 2001: 138). Innymi słowy homonimia polega na wyrażaniu różnych znaczeń za pomocą identycznej formy językowej; np.: „Zamek” - w języku angielskim: 1. castle (budowla); 2. lock (urządzenie do zamykania drzwi); 3. halving (wiązanie); w języku francuskim: 1. château (budowla); 2. serrure (urządzenie do zamykania drzwi). Różnice zakresie znaczenia powyższych homonimów są dosyć wyraźne więc znalezienie ekwiwalentów nie stwarza zbyt wielu trudności. Problem pojawia się w przypadku słów wieloznacznych, których wartość znaczeniowa charakteryzuje się bardziej subtelnymi różnicami; np.: thumacz pisemny to translator, a thumacz ustny to interpreter.

Ekwiwalenty pozorne są także źródłem błędów leksykalnych. Ekwiwalenty pozorne można podzielić na trzy grupy: (i) pseudoekwiwalenty; (ii) ekwiwalenty zmodyfikowane; (iii) ekwiwalenty zróżnicowane. Ekwiwalenty pozorne (faux-amis) to wyrazy o tej samej etymologii i podobnej formie, ale różnych znaczeniach. Słowa te, zachowują podobną pisownię bądź wymowę, lecz w rzeczywistości odsyłają do pojęć zupełnie innych. „Najczęściej błąd ten popełniają osoby, których znajomość języka wyjściowego jest niewystarczająca. Najbardziej charakterystycznymi przykładami angielsko-polskich faux-amis są takie wyrazy jak actually i aktualny (actually znaczy właściwie, w gruncie rzeczy, ale nigdy nie znaczy aktualnie)" (Hejwowski 2004: 128). Ekwiwalenty zmodyfikowane to wyrazy, zachowujące ten sam rdzeń i to samo znaczenie, ale przyjmujące nieco inną formę, np.: epidemia - epidemics. Z kolei „ekwiwalenty zróżnicowane obejmują przypadki, kiedy - mimo istnienia pokrewnych wyrazów angielskich (lub w innych językach zachodnioeuropejskich, które miały wpływ na rozwój języka angielskiego) - odpowiedniki angielskie wyrazów polskich są różne pod względem etymologicznym" (Dzierżanowska 1990: 95). Przykładowo, dla polskiego wyrazu analfabeta pokrewny wyraz angielski lub zachodnioeuropejski to alphabet podczas gdy właściwym ekwiwalentem angielskim jest illiterate.

Błędy wynikające $\mathrm{z}$ różnic terminologicznych są również często spotykane w thumaczeniu. Błędy terminologiczne w tłumaczeniu specjalistycznym są głównie wynikiem braku znajomości terminologii języka specjalistycznego u tłumacza. Ponadto, „błędy w terminologii powstają na ogół na 
skutek użycia wyrazu właściwego dla kultury języka oryginału, a nie używanego w tym sensie w $\mathrm{TL}^{4 \text {, }}$ (Dzierżanowska 1990: 96). Do tego typu błędów można zaliczyć: niewłaściwe zastosowanie technik zapewniania ekwiwalencji dla terminów bezekwiwalentowych, w przypadku terminów, które mają ekwiwalenty. Pod pojęciem termin bezekwiwalentowy należy rozumieć taki termin, który nazywa byt istniejący w rzeczywistości prawnej języka źródłowego, ale nie istniejący w rzeczywistości prawnej języka docelowego. Do takich terminów niewątpliwie można zaliczyć francuskie terminy: chargé d'affaires, acquis communautaire. W przypadku takich terminów thumacz ma do wyboru wiele strategii thumaczeniowych (Kierzkowska 1991), (Vinay, J.-P., Darbelnet J. 1966). Oto niektóre z nich:

a) egzotyk, czyli rodzaj zapożyczenia zachowujący pisownię terminu języka docelowego, np.: chargé d'affaires, acquis communautaire;

b) zapożyczenie $\mathrm{z}$ dostosowaniem pisowni do zasad rządzących językiem docelowym, np.: departament, dystrykt, kanton, dyrektoriat, konstytuanta, komuna, mer, żyrondysta;

c) kalka: coup d'État - zamach stanu; Corps Législatif - Ciało Ustawodawcze; Charte constitutionnelle - Karta konstytucyjna; Empire Français - Imperium Francuskie;

d) ekwiwalent funkcjonalny, czyli zastosowanie najbliższego ekwiwalentu znanego w rzeczywistości prawnej języka docelowego, np.: gmina - commune; województwo arondissement;

e) neologizm, czyli ukucie zupełnie nowego terminu nieznanego w kulturze języka docelowego $\mathrm{np}$.: laissez faire, laissez passer - leseferyzm;

f) ekwiwalent opisowy w postaci definicji, np.: Communauté Française jako organizacja, która wykształciła się w wyniku reorganizacji Unii Francuskiej powstałej w 1946 roku; laissez faire, laissez passer - pozwólcie działać, zostawcie sprawy własnemu losowi;

g) ekwiwalent opisowy nawiązujący do podobnego pojęcia znanego w kulturze języka docelowego np.: kodeks postepowania karnego - Code d'instruction criminelle;

h) dwa terminy na oznaczenie jednego, np.: spótka - société et compagnie;

i) ekwiwalent zorientowany na język źródłowy modyfikujący termin znany w kulturze języka docelowego, np.: Gouvernement Provisoire de la République - Rząd Tymczasowy Republiki Francuskiej;

j) ekwiwalent zawierający w sobie termin języka źródłowego (hiperonim), ale szerszy znaczeniowo np.: société - spótka; compagnie - spótka

k) ekwiwalent ograniczający (hiponim) np.: spótka - société;

Ponadto, należy pamiętać, że każda dyscyplina naukowa posiada własną terminologię (Dzierżanowska 1990: 96), więc polski wyraz próg, to w budownictwie threshold, a próg w muzyce to fret, czyli istnieją dwa różne określenia terminologiczne stosowane w zależności od dziedziny naukowej, do której należy thumaczony tekst. Tłumacz musi zatem być świadom istnienia takich różnic, a w razie wątpliwości najbezpieczniej jest odwołać się do wiedzy ekspertów z danej dziedziny naukowej.

Błędy wynikające z niezgodności leksykalnej grup wyrazowych są wynikiem niepoprawnego tworzenia związków frazeologicznych, pod wpływem interferencji języka thumaczonego tekstu. Błędy te polegają na naruszeniu związku frazeologicznego (w wyniku, którego zostaje utworzony nowy związek frazeologiczny, albo w wyniku którego thumacz tworzy związek frazeologiczny w języku docelowym, jednakże ze zmienionym znaczeniem), co jest konsekwencją nieznajomości frazeologii języka prawnego przez thumacza. Związek frazeologiczny to ustalone $w$ danym języku połączenie co najmniej dwóch wyrazów. Stopień zespolenia poszczególnych wyrazów może być różny. Kurkowska, Skorupka (2001: 155) dzielą je na związki stałe, łączliwe i luźne. Dla thumaczy najważniejsza jest znajomość zasad stosowania związków stałych, czyli wyrażeń idiomatycznych, jak również związków łączliwych, czyli kolokacji zarówno w języku przekładu, jak i w języku oryginalnego tekstu. W teorii Lewickiego (1987) wyróżnia się trzy rodzaje frazeologizmów:

(i) idiomy - połączenia wyrazowe, których znaczenie jest inne niż suma znaczeń komponentów; znaczenie realne nie jest jednoznaczne ze znaczeniem strukturalnym, np.: act of God (siła wyższa);

(ii) frazemy - utrwalone połączenia wyrazów, których sens mieści się w zakresie znaczenia wyrazu nadrzędnego, np.: wnieść sprawę do sądu, termin zawity;

\footnotetext{
${ }^{4}$ Target language, czyli język docelowy.
} 
(iii) zestawienia, czyli wielowyrazowe jednostki z pogranicza frazeologizmów i grup składniowych, np.: postępowanie upadłościowe, umowa sprzedaży, wszczęcie postępowania.

Idiomy są warstwą frazeologii „najbardziej odporną na wpływy obce i najrzadziej przenoszoną z jednego języka do drugiego" (Kurkowska, Skorupka 2001: 166). Rzadko zdarza się sytuacja, aby idiomy w jednym języku tworzone były identycznie jak w drugim (Dzierżanowska 1990: 31). $\mathrm{Z}$ reguły jednak elementy w wyrażeniach idiomatycznych są całkowicie różne.

Tworzenie kolokacji nie jest dowolne i jest powiązane z zagadnieniem znaczenia. Niewłaściwe kolokacje są często przyczyną błędów. „W języku ojczystym tworzenie kolokacji jest czynnością instynktowną" (Dzierżanowska 1990: 32). Przykładowo, każdy Polak powie: realizować plan lub zamierzenie; świadczyć ustugi; przeprowadzać modernizację. Wiadomo, że w języku polskim wpływ się wywiera, ale wplywy się ma. Przymiotnik mały może być użyty w sensie: drobny, nikty, słaby, ale puls jest słaby; nadzieja nikła, a powód błahy. Kolokacje w języku obcym powstają według określonych zasad. Przykładowo, przymiotnik święty w języku angielskim można przetłumaczyć jako holy, saintly, pious, ale Saint Peter, the Holy Ghost. Kolokacji w języku obcym trzeba się nauczyć i zapamiętać, lub używać po sprawdzeniu w słowniku. Nie należy tworzyć ich samodzielnie. Ponadto, każdy język posiada swe własne, odrębne i odporne na zmiany frazeologizmy, związane nierozerwalnie z jego przeszłością i kulturą, np. czarna polewka (symbol odmowy ręki panny). Ze względu na ich nieprzekładalność na inny język, powinny być traktowane ze szczególną ostrożnością $\mathrm{w}$ procesie thumaczenia. Najmniejsze naruszenie struktury frazeologizmu sprawia, że tracą swe znaczenie. Najczęstsze błędy frazeologiczne to:

a) zmiana składu leksykalnego związku (usunięcie, dodanie, wymiana jednego ze zwrotów na inny);

b) kontaminacja frazeologiczna czyli „zmieszanie się, skrzyżowanie dwóch jednostek językowych, dające w wyniku nową jednostkę" (Polański 2003: 313). Zmieszanie takie daje z reguły błędne połączenie. Zazwyczaj kontaminacji ulegają związki stałe lub łączliwe, np.: Swoim pojawieniem się w klasie pokrzyżowat jej szyki (krzyżować plany + mieszać szyki);

c) tautologia (połączenie wyrazowe składające się z wyrazów o takich samych znaczeniach lub bliskoznacznych), np.: sporadyczny, odosobniony przypadek, albo fakty autentyczne; pleonazm (wyrażenie lub zwrot, którego składniki powtarzają niepotrzebnie tę samą treść), np.: Z perspektywy czasu wydarzenie wydawato się błahe i nieważne; Na jej widok cofnąt się z przerażenia do tytu;

d) zbyt dosłowne rozumienie zwrotów i wyrażeń;

e) umieszczenie frazeologizmu w niewłaściwym kontekście;

f) zmiana formy jednego $\mathrm{z}$ elementów (formy morfologicznej, postaci słowotwórczej, przekształcenie konstrukcji składniowej).

W rozporządzeniu nr 1346/2000 błędy leksykalne podzielono na następujące grupy:

$>$ błędy frazeologiczne;

$>$ neologizmy leksykalne;

zmiana znaczenia (błędy terminologiczne).

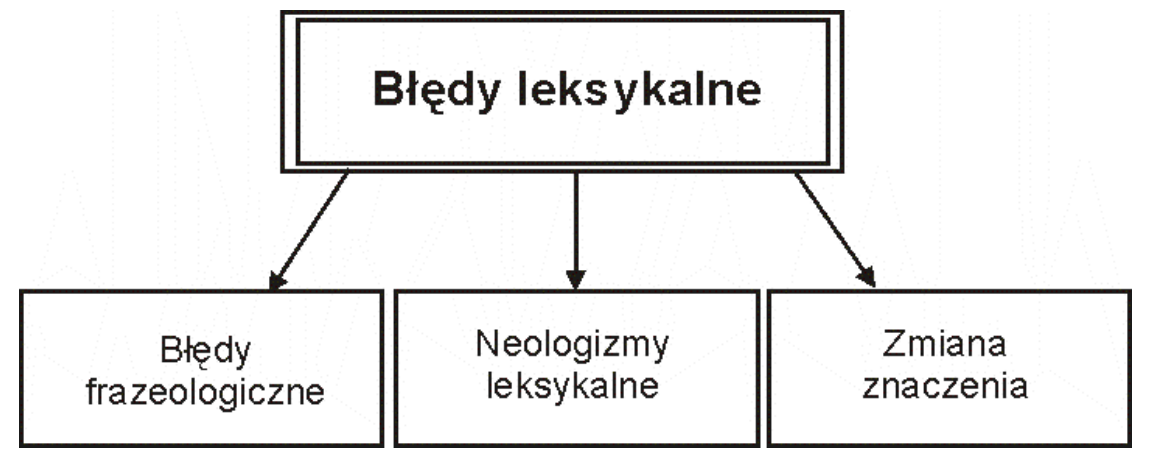

Schemat 7. Podziat błędów leksykalnych 
Błędy frazeologiczne

Przykład 1:

D art. 3 ust. $1 \mathrm{w}$ trakcie przekładu również doszło do naruszenia związku frazeologicznego. Angielski termin in the absence of proof to the contrary przetłumaczono jako dopóki dowód przeciwny nie zostanie wykazany zamiast dopóki dowód przeciwny nie zostanie przeprowadzony - brak zmiany znaczenia, można się domyśleć znaczenia właściwego, ale nie jest to związek frazeologiczny istniejący w języku prawnym. W polskim języku prawnym dowód się przeprowadza a nie wykazuje.

\section{Przykład 2:}

$>\mathrm{w}$ art. 3 ust. 1 fragment $\mathrm{z}$ wersji angielskiej The courts of the Member State (...) shall have jurisdiction to open insolvency proceedings (franc. Les juridictions de l'État membre (...) sont compétentes pour ouvrir une procédure d'insolvbilité) zamiast Sądy Państwa Członkowskiego (...) są właściwe dla wszczęcia postępowania w sprawie niewypłacalności $\mathrm{w}$ thumaczeniu występuje Sądy Państwa Członkowskiego (...) są właściwe do wszczynania postępowania upadłościowego, który jest błędem kolokacji i jednocześnie błędem ze względu na aspektualność.

Neologizmy leksykalne

Przykład 1:

$>\mathrm{w}$ art. $3 \mathrm{w}$ trakcie przekładu angielskiego terminu International jurisdiction (franc. Compétence internationale) na język polski, ukuty został neologizm leksykalny Jurysdykcja międzynarodowa zamiast Jurysdykcja lub Jurysdykcja krajowa. Ukucie takiego terminu przez thumacza jest posunięciem nieuzasadnionym. Stworzył on nowy termin będący kalką z języka angielskiego.

Przykład 2:

$>$ w art. 5 ust. 2 lit. a) angielski termin mortgage (franc. hypothéque) przetłumaczony na język polski jako zastaw hipoteczny jest przykładem na ukucie neologizmu leksykalnego, nie istniejącego w polskim prawie. Tłumacz najwyraźniej błędnie ukuł nowy ekwiwalent zorientowany na język źródłowy modyfikujący termin znany w kulturze języka docelowego. Natomiast, w polskim prawie występuje albo zastaw albo hipoteka. W polskim systemie prawnym zabezpieczeniem rzeczowym na nieruchomości jest hipoteka. Podczas gdy zastaw jest prawem rzeczowym upoważniającym wierzyciela do zaspokojenia wierzytelności z rzeczy ruchomej. W niniejszym rozporządzeniu jest mowa o zabezpieczeniu na nieruchomości tj. o hipotece. Być może tłumacz uniknąłby tego błędu posługując się wersją francuską, gdzie termin hypothéque oznacza hipotekę.

\section{Zmiana znaczenia (błędy terminologiczne)}

Przykład 1:

$>$ w art. 4 ust. 2 lit. b) angielski termin the assets which form part of the estate (franc. les biens qui font objet du dessaisissement) w tłumaczeniu występuje jako aktywa, stanowiące część nieruchomości zamiast składniki majątkowe wchodzące w skład majątku dłużnika (lub masy upadłości). Przyczyną błędu był angielski termin estate, który ma wiele znaczeń. Może on oznaczać majątek, tytuł prawny do nieruchomości, ale także nieruchomość: real estate, lub masę upadłości: bankruptcy estate (posługiwanie się tekstem francuskim pozwoliłoby uniknąć tego błędu) - mamy tutaj do czynienia ze zmianą znaczenia.

Przykład 2:

$>$ wielokrotnie powtarzającym się błędem jest thumaczenie angielskiego terminu assets (franc. biens) jako aktywa zamiast majątek lub składnik majątku - co prowadzi do niespójności tekstu.

Przykład 3:

$>$ Równie często spotykanym błędem jest thumaczenie angielskiego terminu the claims (franc. les créances) jako roszczenia zamiast wierzytelności - co jak w powyższym przykładzie również prowadzi do powstawania licznych niespójności w tekście. 
Przykład 4:

$>\mathrm{w}$ art. 13 na uwagę zasługuje błąd, dotyczący tłumaczenia angielskiego terminu an act (franc. un acte), który powinien zostać przetłumaczony jako czynność, natomiast został błędnie przetłumaczony jako dokument, co spowodowało, że w konsekwencji mamy do czynienia z zaskarżeniem dokumentów dłużnika, zamiast z zaskarżeniem czynności dłużnika.

\subsection{Pozostałe błędy}

Błędy, które zostaną omówione w niniejszej części pracy, występują z reguły w tekście docelowym I zostały zdefiniowane przez Tomaszkiewicz i Pisarską (1996: 144) w następujący sposób:

„Ten typ błędów wynika z kilku przesłanek: (i) ze zbyt bliskich kontaktów między językami, kiedy to formy języka źródłowego wpływają na formę przyjętą w języku docelowym, (ii) $\mathrm{z}$ niezrozumienia tekstu oryginału przez tłumacza, (iii) $\mathrm{z}$ nieprzystawania tekstu przekładu do tekstu oryginału, w którym albo zatracono pewne informacje istotne, albo dodano jakieś informacje, albo w interpretacji zbyt oddalono się od intencji oryginału".

Interferencja, zachodząca w kontakcie między dwoma językami (polegająca na wprowadzeniu do tekstu thumaczenia form, wziętych bezpośrednio z języka źródłowego), na którą tłumacz jest stale narażony, może zachodzić na wszystkich poziomach językowych, tzn. morfologicznym, leksykalnym, składniowym, stylistycznym i kulturowym i często jest źródłem błędów. Ponadto, błędy wynikające z niezrozumienia tekstu, to błędy przekładu, pojawiające się wówczas, kiedy tłumacz nie zrozumiał intencji autora tekstu. Błędy tego typu mogą mieć różny charakter.

$>$ Sens fałszywy, inny niż w oryginale. Według Pisarskiej i Tomaszkiewicz (1996: 146) „są to pewnego rodzaju przesunięcia sensu. Najczęściej ich powodem jest omawiane wyżej zjawisko interferencji. Tłumacz zasugerowany podobieństwem form w dwóch językach jedną zastępuje drugą, ale efekt końcowy nie jest taki sam, np.: 1. Ce pays a des problèmes au niveau économique et politique (Ten kraj ma problemy na poziomie ekonomicznym i politycznym); 2. L'économie de ce pays est en état lamentable (Ekonomia tego państwa znajduje się $\mathrm{w}$ opłakanym stanie). O ile w pierwszym zdaniu można było po polsku powiedzieć problemy na poziomie ekonomicznym i politycznym, o tyle $\mathrm{w}$ drugim wypadku interferencja języka francuskiego spowodowała otrzymanie w thumaczeniu innego sensu niż w oryginale: chodzi o gospodarkę kraju a nie ekonomię".

$>$ Sens przeciwny (znaczenie przeciwne) to błąd znacznie poważniejszy niż sens fałszywy, ponieważ zmienia zupełnie intencję autora. „Okazuje się, że w thumaczeniu mówi się o czymś innym lub $\mathrm{w}$ inny sposób niż $\mathrm{w}$ tekście oryginału, np.: Encore hier il l'ignorait mais aujourd'hui ils sont de très bons amis. (Jeszcze wczoraj ją ignorował, a dzisiaj są bardzo dobrymi przyjaciółmi). Mamy tu do czynienia z sensem przeciwnym. Po polsku czasownik ignorować znaczy znać, ale udawać że się nie zna, natomiast po francusku znaczy nie znać. Poza tym po polsku chodzi o czasownik o zabarwieniu pejoratywnym, a po francusku nie. Tłumacz dał się ponieść interferencji i w konsekwencji uzyskał sens przeciwny" (Pisarska, Tomaszkiewicz 1996: 147).

$>$ Nonsens ,jest to błąd thumaczeniowy, który polega na przypisaniu jakiemuś fragmentowi tekstu wyjściowego na tyle zmienionego sensu, że w efekcie otrzymujemy wyrażenie lub sformułowanie kompletnie absurdalne. (...) nonsens jest uważany za najpoważniejszy błąd przekładowy, np.: Middle age men are the prime victims of workaholizm (franc. La plupart des intoxiqués du travail sont des hommes du Moyen Âge; pol. Średniowieczni mężczyźni sa pierwszymi ofiarami pracoholizmu)" (Delisle 2004: 68). Dwie bezsensowne wersje angielskiego zdania, są wynikiem dosłownego przetłumaczenia middle age men jako średniowieczni, a przecież w tym przypadku chodzi o mężczyzn w średnim wieku.

Wiele błędów $\mathrm{w}$ tłumaczeniu wynika $\mathrm{z}$ niezgodności informacji znaczących $\mathrm{w}$ stosunku do oryginału (Pisarska, Tomaszkiewicz 1996). Oto niektóre z nich:

> Zbyt mała ilość informacji - głównie „chodzi tu o błąd wynikający z niezastosowania zasady kompensacji, to znaczy z niezrównoważenia braku jakiejś informacji w innym miejscu tekstu lub niewyjaśnienia czegoś, co odbiorca tłumaczenia nie jest w stanie zrozumieć" (Pisarska, 
Tomaszkiewicz 1996: 148). Zbyt mała ilość informacji przejawiać się może również w opuszczeniach, (przy czym należy pamiętać, że nie zawsze są one błędem, ponieważ gdy pewne informacje wynikają $z$ innych na zasadzie implikacji, to thumacz może je pominąć). Luki w przekładzie, inaczej opuszczenia nazywa są niekiedy „nieadekwatnością semantyczną" (Dzierżanowska 1990: 101). Są to błędy polegające na opuszczeniu pewnych elementów, bądź nawet całych zdań tekstu w trakcie przekładu. Mogą to być elementy nieznane, bądź terminy, których przekład sprawia trudności tłumaczowi. Opuszczenia te mają wpływ na wierność tłumaczenia. „Pokusa opuszczenia fragmentu tekstu pojawia się wtedy, gdy tłumacz nie rozumie danego sformułowania lub nie potrafi znaleźć zadowalającego ekwiwalentu w języku docelowym. Tego typu trudności świadczą na ogół olukach w kompetencji tłumaczeniowej, a nie o tym, że opuszczenie jest rzeczywiście uzasadnione" (Hejwowski 2004: 144). Należy przy tym jednak podkreślić, że eliminowanie elementów nieistotnych, które niczego nie wnoszą do treści thumaczeniowej jest czynnością celową i wręcz wskazaną, dlatego też nie może być rozpatrywane w kategorii błędu. Jednak, zbyt duża ingerencja thumacza $\mathrm{w}$ tekst jest błędem.

$>\mathrm{Za}$ duża ilość informacji - „Generalnie ten błąd polega na podaniu w tekście przekładu explicite tego, co powinno zostać implicite" (Pisarska, Tomaszkiewicz 1996: 149). Przykładowo: ne pas se pencher au dehors czyli nie wychylać się na zewnątrz, (podczas gdy po polsku w tym kontekście istnieje wyrażenie idiomatyczne: nie wychylać się). Ponadto, należy przy tym podkreślić, że nieuzasadnione dodanie informacji w trakcie przekładu jest również poważnym błędem. Może prowadzić do zmiany znaczenia tłumaczonego tekstu.

> Wolny przekład - tłumacz w przekładzie oddala się od tekstu oryginału poprzez liczne opuszczenia $w$ jednych miejscach i dodawanie informacji w innych, gdy czynność ta nie ma żadnego uzasadnienia. Przekład wolny dotyczy całego tekstu a nie jakiegoś jednego elementu. W przekładzie wolnym, bardzo ważne jest zachowanie proporcji w całym tekście, między informacjami, które wyrażają faktycznie idee autora i tymi informacjami, które są indywidualną interpretacją tłumacza.

Oprócz wcześniej wymienionych błędów (ortograficznych, interpunkcyjnych, stylistycznych, gramatycznych i leksykalnych) w rozporządzeniu znaleziono również inne błędy, a mianowicie:

$>$ dodanie;

$>$ opuszczenie;

$>$ nonsens;

$>$ inne przypadki zmiany znaczenia.

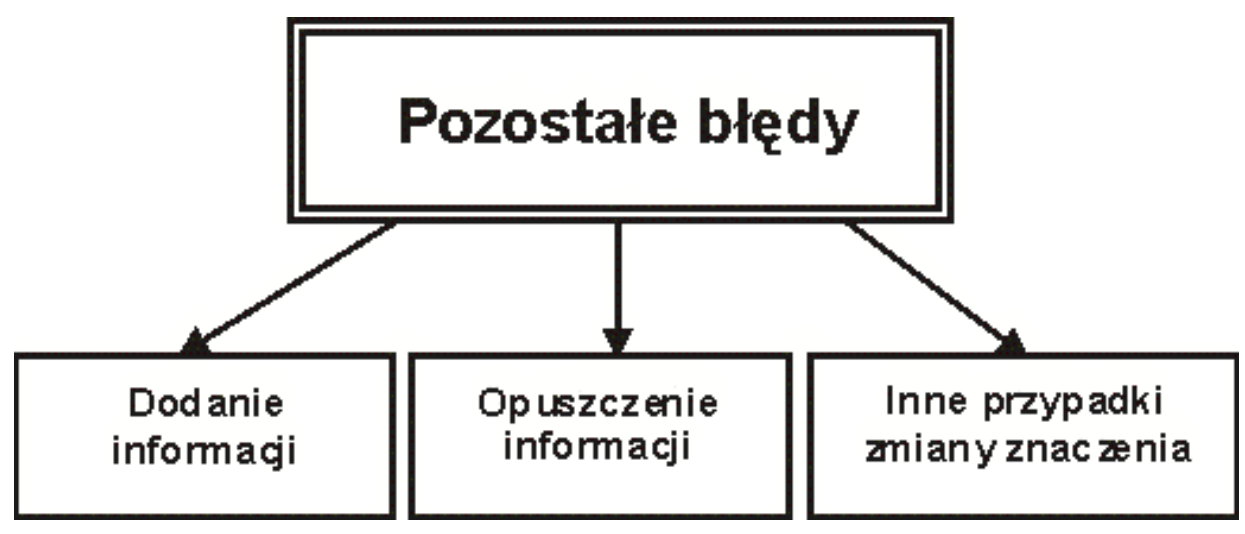

Schemat 8: Podziat pozostatych btędów

Oto przykłady poszczególnych błędów:

Dodanie

Przykład 1:

$>\quad \mathrm{w}$ art. 7 ust. $1 \mathrm{w}$ polskim thumaczeniu zamieszczono uzasadnione prawa zbywcy dla angielskiego terminu the seller's rights (franc. les droits du vendeur) zamiast prawa zbywcy. Dodanie przez 
tłumacza przymiotnika uzasadnione, pociąga za sobą zmianę znaczenia, ponieważ można zinterpretować uzasadnione prawa zbywcy jako uprawnienie sądu do weryfikacji tych praw. Takie uprawnienie może nadać sądom ustawodawca, a w tym przypadku, w thumaczeniu nadaje je tłumacz. Tak, więc w tym miejscu tłumacz pozwolił sobie na całkowitą zmianę znaczenia.

Przykład 2:

$>$ art. 4 ust 2. lit. b) angielski termin the treatement of assets acquired by or devolving on the debtor after the opening of the insolvency proceedings powinien zostać przetlumaczony jako sposób postępowania $\mathrm{z}$ majątkiem nabytym przez dłużnika po wszczęciu postępowania upadłościowego podobnie jak to widnieje w wersji francuskiej (le sort des biens acquis par le débiteur après l'ouverture de la procédure d'insolvabilité). Zamiast tego, w thumaczeniu UKIE, została dodana informacja, $\mathrm{w}$ wyniku czego czytamy: postępowanie $\mathrm{z}$ aktywami nabytymi przez lub przekazanymi zakładowi ubezpieczeń po otwarciu postępowania upadłościowego. Ani w wersji angielskiej, ani francuskiej nie ma jakiejkolwiek informacji na temat zakładu ubezpieczeń. Po raz kolejny zatem, mamy do czynienia z nieuzasadnionym dodaniem informacji przez thumacza i ze zmianą znaczenia.

Przykład 3:

$>$ w art. 4 ust 2. lit. d) podczas thumaczenia angielskiego fragmentu the conditions under which setoffs may be invoked (franc. les conditions d'opposabilité d'une compensation) w polskiej wersji została dodana informacja warunki dokonywania potrąceń $\underline{z}$ tytułu roszczeń a powinno być przesłanki dokonywania potrąceń lub skuteczności potrącenia. Tłumacz, zatem dodał informacje popełniając przy tym równocześnie błąd terminologiczny.

Opuszczenie

Przykład 1:

$>\mathrm{w}$ art. 2 lit e) $\mathrm{w}$ trakcie przekładu angielskiego terminu judgment in relation to the opening of insolvency proceedings or the appointment of a liquidator shall include the decision of any court empowered to open such proceedings or to appoint a liquidator (franc. < décision>: lorsqu'il s'agit de l'ouverture d'une procédure d'insolvabilité ou de la nomination d'un syndic, la décision de toute juridiction compétente pour ouvrir une telle procédure ou pour nommer un syndic) thumacz opuścił słowo any. Tak więc, w thumaczeniu na język polski czytamy: [...] sądu właściwego, zamiast każdego sądu właściwego, co pozwala w konsekwencji na różną wykładnię.

Przykład 2:

$>\quad$ w art. 4 ust 2. lit. a) tłumacz opuścił w trakcie przekładu istotną informację. Angielski fragment against which debtors insolvency proceedings may be brought on account of their capacity (franc. les débiteurs susceptibles de faire l'objet d'une procédure d'insolvabilité du fait de leur qualité) w tłumaczeniu na język polski brzmi: dłużników, przeciw którym postępowania upadłościowe mogą zostać wszczęta, biorąc pod uwagę ich zdolność [...], a powinien on zostać przetłumaczony $\mathrm{w}$ następujący sposób: dłużników, w stosunku, do których postępowanie w sprawie niewypłacalności może zostać wszczęte, biorąc pod uwagę ich zdolność do upadłości. $\mathrm{W}$ tym przypadku opuszczenie fragmentu do upadłości pozwala na różną wykładnię i może prowadzić w konsekwencji do zmiany znaczenia.

\section{Przykład 3:}

$>$ w art. 4 lit. i) w thumaczeniu angielskiego fragmentu: the rules governing the distribution of proceeds from the realisation of assets, the ranking of claims and the rights of creditors who have obtained partial satisfaction after the opening of insolvency proceedings by virtue of a right in rem or through a set-off (franc. les règles de distribution du produit de la réalisation des biens, le rang des créances et les droits des créanciers qui ont été partiellement désintéressés après l'ouverture de la procédure d'insolvabilité en vertu d'un droit réel ou par l'effet d'une compensation) $\mathrm{w}$ wersji polskiej zabrakło słowa zaspokojenia, tak więc $\mathrm{w}$ thumaczeniu czytamy: zasady podziału dochodów uzyskanych $\mathrm{z}$ upłynnionych aktywów, kolejność [...] roszczeń oraz prawa wierzycieli, częściowo zaspokojonych po otwarciu postępowania upadłościowego na podstawie prawa rzeczowego lub wskutek dokonanych potrąceń, zamiast tłumaczenia: zasady podziału środków uzyskanych z likwidacji składników majątku, kolejność zaspokojenia 
wierzytelności oraz prawa wierzycieli, częściowo zaspokojonych po wszczęciu postępowania W sprawie niewypłacalności na podstawie prawa rzeczowego lub wskutek potrącenia. Opuszczenie informacji w tym przypadku pozwala na różną wykładnię, np.: kolejność powstawania roszczeń. Jednocześnie mamy tu do czynienia z błędami terminologicznymi.

Nonsens

Przykład 1:

$>$ w art. 5 ust. 2 lit. b) angielskie zdanie the exclusive right to have a claim met, in particular a right guaranteed by a lien in respect of the claim or by assignment of the claim by way of a guarantee (franc. le droit exclusif de recouvrer une créance, en vertu de la mise en gage ou de la cession de cette créance à titre de garantie) powinno być przetłumaczone jako wyłączne prawo ściągania wierzytelności, w szczególności z tytułu zastawu na wierzytelności lub prawo przelewu tej wierzytelności na zabezpieczenie, natomiast zostało błędnie przetłumaczone jako wyłączne prawo ściągania należności, w szczególności prawo gwarantowane przez prawo zastawu w odniesieniu do należności poprzez przewłaszczenie należności przez gwarancje. W tym przypadku, błąd wynika z braku znajomości składni języka angielskiego, a dokładniej z nieumiejętności przethumaczenia fragmentu or by. Tłumacz nie zrozumiał fragmentu: or by. Nie potrafił dokonać rozbioru zdań i nie zrozumiał do czego odnosi się by, więc opuścił or i odniósł by do ostatniego rzeczownika. Mamy w tym przypadku również do czynienia $\mathrm{z}$ opuszczeniem spójnika, nieznajomością terminologii, jak również próbą przekładu słowo w słowo.

Przykład 2:

$>$ w ust. $22 \mathrm{w}$ preambule, angielskie zdanie The decision of the first court to open proceedings should be recognised in the other Member States without those Member States having the power to scrutinise the court's decision (franc. La décision de la juridiction qui ouvre la première la procédure devrait être reconnue dans tous les autres États membres, sans que ceux-ci aient la faculté de soumettre la décision de cette juridiction à un contrôle) zostało przetłumaczone jako Postanowienie sądu o wszczęciu pierwszego postępowania jest uznawane $\mathrm{w}$ pozostałych Państwach Członkowskich, bez poddawania tego postanowienia dokładnej analizie, zamiast Orzeczenie sądu, który jako pierwszy wszczał postępowanie powinno zostać uznane w pozostałych Państwach Członkowskich, bez możliwości badania tego orzeczenia sądu przez te Państwa Członkowskie. W tym przypadku, tłumacz wyraźnie nie zrozumiał treści tłumaczonego tekstu. Orzeczenie sądu, który jako pierwszy wszczął postępowanie to nie to samo co wszczęcie pierwszego postępowania.

Przykład 3:

$>$ w kilku miejscach angielskie zdanie: the opening of insolvency proceedings (franc. l'ouverture de la procédure de l'insolvabilité) zozstało przetłumaczone jako uruchomienie środków odnoszących się do reorganizacji lub otwarcie postępowania likwidacyjnego zamiast wszczęcie postępowania w sprawie niewypłacalności. Ten błąd świadczy o analfabetyzmie prawniczym.

Inne przypadki zmiany znaczenia

Przykład 1:

$>\mathrm{w}$ art. $36 \mathrm{w}$ trakcie tłumaczenia pomylone zostały numery artykułów. W wersji angielskiej występowały articles 31 to 35 (franc. les articles 31 à 35) podczas gdy w wersji polskiej art. 33-35. Błąd ten jest przykładem błędu prowadzącego do zmiany znaczenia, a spowodowanego nieprofesjonalnym podejściem do powierzonego zadania, bądź po prostu zwykłym niechlujstwem.

Przykład 2:

$>$ podobnie $\mathrm{w}$ art. 3 ust. 4 , gdzie $\mathrm{w}$ trakcie thumaczenia doszło do pomylenia numeru ustępu. $\mathrm{W}$ wersji angielskiej i francuskiej występował paragraph 1 (franc. paragraphe 1), podczas gdy w wersji polskiej ust. 2, co doprowadziło do zmiany znaczenia.

Przykład 3:

$>$ w art. 44 ust.1 lit e) thumacz zastosował złą strategię thumaczenia. Zamiast Podpisaną dnia 27 lutego 1979 r. w Wiedniu francusko-austriacką Konwencję o właściwości sądów, uznawaniu $\mathrm{i}$ wykonywaniu orzeczeń sądowych $\mathrm{w}$ zakresie prawa upadłościowego thumacz napisał: Konwencję zawartą między Francją a Austrią w sprawie jurysdykcji, uznawania i wykonywania orzeczeń o upadłości, podpisaną w Wiedniu dnia 27 lutego 1979 r. 


\section{Podsumowanie}

Zawód thumacza jest niezwykle trudny. Wymaga nie tylko solidnego i specjalistycznego wykształcenia, odpowiednich predyspozycji ale również ustawicznego dokształcania się. Aby wykonywać rzetelnie pracę tłumacza, konieczne są przede wszystkim właściwe kompetencje (w zakresie znajomości języka obcego jak i ojczystego, dziedziny do której należy thumaczony tekst, strategii thumaczeniowych, czy też zasad przekładu). Analizując błędy, występujące w rozporządzeniu nr 1346/2000 można bardzo szybko zauważyć, że tłumacz nie posiadał wystarczających kompetencji potrzebnych do tłumaczenia tekstu sformułowanego w języku prawa.

Warunkiem wstępnym i koniecznym, aczkolwiek niewystarczającym do wykonywania zawodu tłumacza jest doskonała znajomość języka obcego, jak również języka ojczystego. Od tłumacza wymaga się znajomości morfologii, składni, stylistyki, leksyki a szczególnie semantyki i ortografii obu języków, oraz wiedzy na temat kultur i narodów posługujących się danym językiem. Niestety, thumaczowi rozporządzenia $\mathrm{nr}$ 1346/2000 najwyraźniej zabrakło podstawowych kompetencji w zakresie znajomości języka angielskiego, o czym świadczą liczne błędy wynikające przykładowo $\mathrm{z}$ niezrozumienia składni języka angielskiego (np.: w przypadku thumaczenia angielskiego fragmentu the exclusive right to have a claim met, in particular a right guaranteed by a lien in respect of the claim or by assignment of the claim by way of a guarantee co w konsekwencji doprowadziło do błędnego thumaczenia: wyłączne prawo ściagania należności, szczególności prawo gwarantowane przez prawo zastawu $w$ odniesieniu do należności poprzez przewłaszczenie należności przez gwarancje, zamiast thumaczenia: wyłaczne prawo ściagania wierzytelności, w szczególności z tytutu zastawu na wierzytelności lub prawo przelewu tej wierzytelności na zabezpieczenie). Tłumacz niewłaściwie wykorzystał również swoją wiedzę z języka polskiego. Czytając rozporządzenie nr 1346/2000 można odnieść wrażenie, że tłumacz nie posiadał wystarczającej wiedzy z zakresu języka polskiego, czego dowodem są liczne błędy gramatyczne (np.: naruszenie związku rządu $\mathrm{w}$ art. 2, gdzie angielski fragment to administer or liquidate assets przetłumaczono jako zarzadzanie lub likwidacja aktywów dlużnika zamiast zarządzanie majątkiem lub likwidacja majątku dlużnika), błędy ortograficzne (np.: państwo wszczęcia postępowania pisane $\mathrm{z}$ małej litery), czy też interpunkcyjne (np.: tylko, jeżeli). Ponadto, obca thumaczowi była również wiedza z zakresu podstawowych zasad formułowania tekstów ustawowych w języku polskim (ZTP, Dz. U. z 2002 r. $\mathrm{Nr}$ 100, poz. 108) oraz znajomości języka prawa, o czym świadczą błędy rejestru (np.: angielski fragment other measure terminating the isolvency przethumaczono jako ktadacy kres niewyplacalności zamiast usuwajacy niewypłacalność), błędy stylistyczne (np.: angielski fragment with the exception of law suits pending przetłumaczono jako $z$ wyjatkiem spraw zawistych przed sadem zamiast $z$ wyłączeniem toczacych się postępowań), jak również liczne niespójności w tekście (np.: thumaczenie angielskiego terminu assets czasami jako aktywa a czasami jako majątek).

Drugim, niezbędnym warunkiem do wykonania dobrego tłumaczenia, jest znajomość przedmiotu i dziedziny, do której należy tłumaczony tekst. Pożądana jest współpraca tłumacza ze specjalistą $\mathrm{z}$ danej dziedziny, chyba, że tłumacz sam jest takim specjalistą (np. jest $\mathrm{z}$ wykształcenia zarówno prawnikiem jak i tłumaczem). Niestety, tłumacz, który tłumaczył rozporządzenie nr 1346/2000 nie był na pewno prawnikiem, ani też z pewnością nie konsultował się z żadnym specjalistą prawnikiem w trakcie thumaczenia tekstu, o czym świadczą liczne błędy terminologiczne jak i frazeologiczne. Można mu zarzucić totalny analfabetyzm prawniczy, a w szczególności kompletny brak znajomości prawa upadłościowego, czego świadectwem są błędy terminologiczne typu: przetłumaczenie angielskiego terminu secondary insolvency proceedings (franc. procédure d'insolvabilité secondaire) jako wtórne postępowanie $w$ sprawie niewyplacalności zamiast uboczne postepowanie $w$ sprawie niewypłacalności; czy też przewijające się przez całe rozporządzenie błędy w thumaczeniu terminów: the claims (franc. créances) thumaczonych jako roszczenia zamiast wierzytelności; podobnie $\mathrm{w}$ thumaczeniu terminu assets (franc. biens) jako aktywa zamiast majątek lub sktadnik majatku.

Thumacz rozporządzenia $\mathrm{nr}$ 1346/2000 nie miał również niezbędnej wiedzy na temat systemów prawnych języków, w obrębie których thumaczył. W wielu miejscach tłumacz posługiwał się wyłącznie wersją angielską, co przyczyniło się do powstania licznych błędów. A przecież, językami aktów prawa Unii, są wszystkie języki Unii. Oprócz wersji angielskiej tłumacz powinien sięgnąć również do innych wersji językowych, np.: francuskiej czy niemieckiej, których aparat pojęciowy 
języka prawniczego jest bliższy polskiemu niż aparat pojęciowy języka angielskiego, wywodzącego się z tradycji common law. Wersje w językach niemieckim i francuskim, które wywodzą się z kolei z tego samego systemu i tradycji co język polski, są o wiele bardziej przystawalne do wersji w języku polskim, a więc posługując się nimi przy thumaczeniu, thumacz uniknąłby w wielu miejscach kompromitujących błędów. Tymczasem, tłumacze UKIE brali pod uwagę wyłącznie tekst angielski, co doprowadziło przykładowo do przetłumaczenia angielskiego terminu the act oznaczającego czynność prawną jako dokument, podczas gdy wystarczyłoby posłużyć się jednoznaczną wersją niemiecką, gdzie używa się terminu Handlung, by uniknąć tego błędu. Podobnie w przypadku thumaczenia już wyżej wspomnianego terminu mortgage, rzut oka na wersje niemiecką - Hypothek, czy też francuską - hypothéque nie pozostawia już żadnych wątpliwości. Także w przypadku thumaczenia angielskiego terminu estate (oznaczającego w podstawowym znaczeniu majątek, ale także nieruchomość: real estate czy też masę upadłości: bankruptcy estate), gdzie odwołanie do wersji niemieckiej (w której występuje termin Masse) albo do francuskiej (gdzie wystąpił termin les biens qui font objet $d u$ dessaisissement) wystarczyłoby, aby rozwiać wszelkie wątpliwości odnośnie thumaczenia tego terminu. Kolejnym dowodem przemawiającym za thumaczeniem z języka francuskiego lub niemieckiego zamiast angielskiego jest błąd powstały w trakcie thumaczenia następującego fragmentu: the opening of the insolvency proceedings, (niem. die Eröffnung des Insolvenzferfahrens (franc. l'ouverture de la procédure d'insolvabilité) jako uruchomienie środków odnoszacych się do reorganizacji lub otwarcie postępowania likwidacyjnego, zamiast wszczęcie postępowania $w$ sprawie niewyptacalności. W tym przypadku, podobnie jak w powyższych przykładach, wgląd w wersję niemiecką czy francuską pozwoliłby uniknąc tego błędu. Błędy frazeologiczne również odzwierciedlają brak znajomości prawa, a w szczególności brak znajomości frazeologii języka prawa, np.: $\mathrm{w}$ thumaczeniu angielskiego terminu in the absence of proof to the contrary czytamy: dopóki dowód przeciwny nie zostanie wykazany zamiast dopóki dowód przeciwny nie zostanie przeprowadzony.

W kompetencji każdego tłumacza leży bardzo dobra znajomość strategii thumaczeniowych. Wybór strategii thumaczeniowej, czyli określonego sposobu postępowania tłumacza $\mathrm{w}$ procesie translacyjnym, jest pierwszym krokiem podejmowanym przez tłumacza przystępującego do wykonania thumaczenia. Wynikiem zastosowania niewłaściwej strategii tłumaczeniowej przez tłumacza rozporządzenia $\mathrm{nr}$ 1346/2000 są liczne neologizmy leksykalne, np.: zastaw hipoteczny utworzony dla angielskiego terminu mortgage, oznaczającego w tym kontekście hipoteke, gdzie tłumacz zastosował technikę zapewniania ekwiwalentów dla terminów bezekwiwalentowych i ukuł zupełnie nowy ekwiwalent - zastaw hipoteczny dla terminu, który posiada już swój ekwiwalent w rzeczywistości prawnej języka polskiego. Podobnie w przypadku terminu international jurisdiction (franc. compétence international) przetlumaczonego jako jurysdykcja międzynarodowa zamiast po prostu jurysdykcja, bądź jurysdykcja krajowa.

Znajomość zasad przekładu ma również istotny wpływ na jakość przekładu. Przykładowo, weryfikacja i korekta przetłumaczonego tekstu to bardzo ważne zasady, których powinien przestrzegać każdy tłumacz. Właśnie podczas weryfikacji zostają na ogół wychwycone ewentualne błędy. Zdarza się jednak, że thumacz nie weryfikuje i nie dokonuje korekty wykonanego thumaczenia, co w efekcie prowadzi do „dopuszczenia do obiegu” tekstów z licznymi błędami i w praktyce doprowadziło już do nie jednego skandalu (tak jak to miało miejsce w przypadku rozporządzenia w sprawie postępowań upadłościowych). Ewidentnymi przykładami braku korekty w wyżej cytowanym rozporządzeniu są błędy dotyczące braku spacji między wyrazami, które przewijają się nagminnie przez całe rozporządzenie, np.: kończacewtórne postępowania $w$ sprawie niewyplaclności, czy też dotyczące zastosowania niewłaściwego znaku interpunkcyjnego np.: kropki zamiast średnika. Te błędy wiążą się nieodzownie z pojęciem solidności i staranności wykonywanego zlecenia. Brak korekty, jest przecież także wynikiem niesolidnego i nieprofesjonalnego podejścia thumacza do powierzonego mu zadania, świadectwem niedbałości, lenistwa, jak i zwykłego niechlujstwa (np.: pomylenie numeru artykułu). Kompetentny i solidny tłumacz powinien również wiedzieć, że nie należy nadmiernie ingerować $\mathrm{w}$ thumaczony tekst. Obowiązkiem moralnym i prawnym każdego thumacza jest wierne i rzetelne oddanie treści thumaczonego tekstu. Może on co prawda ingerować w tekst, jeżeli jest to konieczne, ale nie ma prawa ingerować w znaczenie tego tekstu. W praktyce okazuje się, że nie wszyscy thumacze o tym pamiętają. Niewątpliwie zapominał o tym thumacz 
rozporządzenia unijnego w sprawie postępowania upadłościowego, który wielokrotnie wprowadza niepożądane zmiany w thumaczony tekst, co uwidacznia się poprzez liczne opuszczenia czy dodania, bądź też w tworzeniu kompletnych nonsensów w thumaczonym tekście, będących wytworem „radosnej, niczym nieuzasadnionej twórczości” wynikającej z kompletnego niezrozumienia thumaczonego fragmentu (np.: the treatement of assets acquired by or devolving on the debtor after the opening of the insolvency proceedings powinien zostać przetłumaczony jako sposób postepowania $z$ tymi składnikami majątku nabytymi przez dlużnika lub mu przekazanymi po wszczęciu postępowania $w$ sprawie niewyplacalności (franc. le sort des biens acquis par le débiteur après l'ouverture de la procédure d'insolvabilité), zamiast tego, tłumacz dodaje informacje: postępowanie z aktywami nabytymi przez lub przekazanymi zakładowi ubezpieczeń po otwarciu postępowania upadtościowego.

Powyższe błędy, wynikające $\mathrm{z}$ braku odpowiednich kompetencji u tłumaczy, skłaniają do refleksji na temat roli thumacza we współczesnym świecie, a przede wszystkim, na temat odpowiedzialności tłumacza za wykonane tłumaczenie. Rola thumacza w kształtującym się społeczeństwie międzynarodowym wzrosła znacząco i wzrasta nieustannie. Dynamiczny rozwój kontaktów międzynarodowych zrodził potrzebę na kadry wykwalifikowanych thumaczy, a w szczególności na tłumaczy specjalistycznych. Tłumacz spełnia w dzisiejszych czasach rolę pośrednika między narodami i kulturami. Umożliwia wymianę informacji, osiągnięć i współpracę międzynarodową.

W obliczu jednoczącej się Europy, w związku z dostosowaniem polskiej gospodarki i prawa do wymogów unijnych, pojawiło się na polskim rynku wiele zleceń dla tłumaczy specjalistycznych, ale jednocześnie pojawili się niestety „niekompetentni chętni” do wykonywania tego zawodu, a w konsekwencji powstały liczne tłumaczenia dokumentów złej jakości. Istotną kwestią, która zdaje się wpływać na jakość przekładu jest przede wszystkim brak odpowiedzialności tłumaczy. Do tej pory, tłumacze w Polsce nie ponosili żadnych konsekwencji za źle przetłumaczony tekst. Niestety sam prawodawca doprowadził do takiej sytuacji, w której thumacz nie ponosi odpowiedzialności ani cywilnej, ani karnej za źle wykonane thumaczenie. Nie ma kogo pociągnąć do odpowiedzialności, ponieważ nigdy nie było $\mathrm{i}$ nadal nie ma jeszcze wymogu, umieszczania nazwiska pod przetłumaczonym tekstem. Zatem, skoro nie ma żadnych sankcji za źle sporządzone thumaczenie, wielu amatorów sztuki przekładu bierze się za thumaczenie i „eksperymentuje” bez podejmowania jakiegokolwiek ryzyka. Niestety, o skandalicznych efektach pracy tychże amatorów słyszy się obecnie bardzo dużo. Można nawet powiedzieć o lawinie błędnych przekładów, powstałych w związku z thumaczeniem unijnych aktów prawnych na język polski, w związku z przystąpieniem Polski do Unii Europejskiej.

Błędy w thumaczeniu, zwłaszcza tekstów technicznych i prawnych, prowadzą do poważnych szkód materialnych przedsiębiorstw, gospodarki jak i państwa. Co więcej, największe straty związane ze źle wykonanym tłumaczeniem ponosi, jak zawsze, zwykły obywatel. W przypadku thumaczenia instrukcji urządzeń elektrycznych, ulotek dotyczących dawkowania lekarstw, czy też thumaczenia w trakcie procesu o morderstwo, skutki błędnego thumaczenia mogą być wręcz sprawą życia i śmierci. Wówczas, odpowiedzialność thumacza za dobrze wykonane thumaczenie wiąże się przede wszystkim z odpowiedzialnością za ludzkie życie. Zatem, tłumacz, zwłaszcza przysięgły, będący osobą zaufania publicznego, powinien przestrzegać zasad etyki zawodowej i odmówić przyjęcia danego zlecenia w przypadku, kiedy nie dysponuje odpowiednimi kompetencjami (np.: wiedzą fachową), niezbędnymi do wykonania danego thumaczenia. Godność i etyka zawodowa nakazują tłumaczowi spełniać wymagania stawiane mu przez społeczeństwo. Dlatego też, thumacz powinien dbać o wysoki poziom umiejętności translatorskich oraz wiedzy merytorycznej poprzez ustawiczne samokształcenie się, śledzenie literatury zawodowej oraz nieustanny kontakt z kulturą i językiem kraju, z którym związany jest zawodowo. Ponadto, powinien on dołożyć wszelkich starań w celu osiągnięcia tłumaczenia najwyższej jakości.

Ostatecznie, po trzech latach, ukazała się poprawiona wersja thumaczenia rozporządzenia 1346/2000 na język polski, która jednak nadal zawiera pewne usterki. 


\section{Bibliografia}

Council Regulation (EC) no 1346/2000 of 29 May 2000 on insolvency proceedings (Official Journal of the European Communities, L 160/1 of 30 June 2000).

David, R. 2002. Les grands systèmes de droit contemporains. Paris: Dalloz

Delisle, J. 1988. Translation: an interpretive Approach. Ottawa/London: University of Ottawa Press.

Delisle, J. 2004. Terminologia tłumaczenia. Poznań: Wydawnictwo Naukowe UAM (tłum. Teresa Tomaszkiewicz)

Dzierżanowska, H. 1990. Przekład tekstów nieliterackich. Warszawa: Państwowe Wydawnictwo Naukowe.

Grucza, F. 1978. Z problematyki błędów obcojęzycznych. Warszawa: Wydawnictwa Szkolne i Pedagogiczne.

Grucza, F. 1986. Problemy translatoryki i dydaktyki translatorycznej. Warszawa: Wydawnictwa Uniwersytetu Warszawskiego.

Grucza, F. 1999. Translacja a kreatywność. [W]: Lingua Legis nr 7. 2-4.

Hejwowski, K. 2004. Kognitywno - komunikacyjna teoria przekładu. Warszawa: Wydawnictwo Naukowe PWN.

Jakubecki, A., Zedler, F. 2003. Prawo upadłościowe i naprawcze. Komentarze Zakamycza. Kraków: Kantor Wydawniczy Zakamycze.

Karczewska, D. 2002. O błędach w tłumaczeniu. [W]: A. Kopczyński, U. Zaliwska-Okrutna (red.). Język rodzimy a język obcy. Komunikacja, przekład, dydaktyka. Warszawa: Wydawnictwa Uniwersytetu Warszawskiego. 129-148.

Kielar, B. Z., 1977. Language of the Law in the Aspect of Translation. Warszawa: Wydawnictwo Uniwersytetu Warszawskiego.

Kielar, B. Z., 2003. TS w układzie międzynarodowej komunikacji zawodowej. [W]: B. Z., Kielar, S. Grucza (red.). Języki specjalistyczne. Lingwistyczna identyfikacja tekstów specjalistycznych. Warszawa: Katedra Języków Specjalistycznych Uniwersytetu Warszawskiego. 121-133.

Kierzkowska, D. 1991. Kodeks tłumacza sądowego. Warszawa: Polskie Towarzystwo Tłumaczy Ekonomicznych, Prawniczych i Sądowych TEPIS.

Kierzkowska, D. 2002. Tłumaczenie prawnicze. Warszawa: Polskie Towarzystwo Tłumaczy Ekonomicznych, Prawniczych i Sądowych TEPIS.

Kozłowska, Z. 2002. O błędach językowych w tekstach polskich przekładów. [W]: A. Kopczyński, U. Zaliwska-Okrutna (red.). Język rodzimy a język obcy. Komunikacja, przekład, dydaktyka. Warszawa: Wydawnictwo Uniwersytetu Warszawskiego. 137-149.

Kurkowska, H., Skorupka, S. 2001. Stylistyka polska. Warszawa: Wydawnictwo Naukowe PWN.

Lewicki, A. M., Pajdzińska, A., Rejakowa, B. 1987. Z zagadnień frazeologii. Problemy leksykograficzne. Warszawa: Wydawnictwo Naukowe PWN.

Lukszyn, J. 1993. Tezaurus terminologii translatorycznej. Warszawa: Wydawnictwo Naukowe PWN.

Łozińska-Małkiewicz, E. 2003. Polsko - francuski słownik terminologii prawniczej. Toruń: Wydawnictwo „EWA” S.C.

Nie czytać po polsku. Gazeta Wyborcza. 10 styczeń 2005.

Pisarska, A., Tomaszkiewicz, T. 1996. Współczesne tendencje przekładoznawcze: Poznań: Wydawnictwo Naukowe UAM.

Pieńkos, E., Pieńkos, J. 1981. Słownik terminologii prawniczej i ekonomicznej francusko - polski. Warszawa: Wiedza Powszechna.

Polański, M. 2003. Encyklopedia językoznawstwa ogólnego. Wrocław: Zakład Narodowy im. Ossolińskich.

Porzycki, M. 2004. Lawina bełkotliwych przekładów. Rzeczypospolita. 26 marzec 2004.

Règlement (CE) No 1346/200 du Conseil du 29 mai 2000 relatif aux procédures d'insolvabilité (Journal officiel des Communautés européennes L 160/1 du 30 juin 2000).

Rozporządzenie prezesa rady ministrów z dnia 20 czerwca 2002r. w sprawie zasad techniki prawodawczej (Dz. U. z dnia 5 lipca 2002 r.).

Rozporządzenie Rady (WE) nr 1346/2000 z dnia 29 maja 2000r. w sprawie postępowania upadłościowego (wersje thumaczenia UKIE z 2003 i 2004, http://www.europa.eu.int/eur-lex/de/accession.html).

Sczaniecki, M. 2003. Powszechna historia państwa i prawa. Warszawa: Wydawnictwo Prawnicze LexisNexis.

Ustawa z dnia 7 października 1999 r. o języku polskim. Dz.U. Nr 90, poz. 999.

Vinay, J-P., Darbelnet, J. 1966. Stylistique comparée du français et de l'anglais. Paris: Didier.

Voellangel, A. 1998. Jak nie thumaczyć tekstów technicznych. Warszawa: TEPIS.

Wierzbicka, A., Wierzbicki, P. 1970. Praktyczna stylistyka. Warszawa: Wiedza Powszechna.

Wierzbicki, P. 2004. Upadłość po europejsku. Gazeta prawna.16 marca 2004.

Wróblewski, B. 1948, Język prawny i prawniczy. Kraków: Polska Akademia Umiejętności.

Zasady techniki prawodawczej (ZTP Dz. U. Z dnia 20 czerwca 2002 r.).

Zedler, F. 2004. Prawo upadłościowe i naprawcze w zarysie. Kraków: Kantor Wydawniczy Zakamycze. 